\title{
Activation and regioselectivity of five-membered cyclic thionocarbamates to nucleophilic attack $\dagger$
}

Cite this: RSC $A d v$., 2013, 3, 24997

\author{
Ismail Awheda, ${ }^{a}$ Nezire Saygili, ${ }^{b}$ A. Christopher Garner ${ }^{a}$ and John D. Wallis*a
}

The cyclic thionocarbamate of alaninol undergoes nucleophilic attack by sulfur nucleophiles at 5-C to give 1-thiopropyl-2-amine derivatives when derivatised on nitrogen with a Boc group. lodide under

Received 5th March 2013

Accepted 3rd October 2013

DOI: $10.1039 / \mathrm{c} 3 \mathrm{ra} 41074 a$

www.rsc.org/advances microwave conditions causes a rearrangement to the isomeric thiazolidinone, while "hard" nucleophiles react at the thione group to yield a variety of product types by subsequent $\mathrm{C}-\mathrm{N}$ or $\mathrm{C}-\mathrm{O}$ cleavage. X-ray crystallography studies showed that the $N$-Boc group reduces delocalisation of electron density from nitrogen into the thione group, and thus promotes activation of the ring to nucleophilic attack.

\section{Introduction}

The increasing availability of enantiopure vic-diols and vicaminoalcohols has stimulated interest in developing synthetic chemistry which makes use of these substances. ${ }^{1,2}$ In particular, activation of the $\mathrm{C}-\mathrm{O}$ bonds to nucleophilic attack at carbon opens up routes to $\alpha$-substituted alcohols and amines. Thus, cyclic sulfate esters 1, prepared from vic-diols in two steps, undergo ring opening with a variety of nucleophiles to give hemisulfates 2 which can be hydrolysed to the substituted alcohols $3 .^{3}$ In some cases two nucleophilic substitutions lead to complete displacement of sulfate. ${ }^{4-7}$ Similarly, vic-aminoalcohols can be converted into cyclic sulfamidates e.g. $\mathbf{4}$ which also undergo nucleophilic substitution with breaking of the $\mathrm{C}-\mathrm{O}\left(\mathrm{SO}_{2}\right)$ bond to produce sulfamate salts 5 which, after hydrolysis with concentrated sulfuric acid, yield substituted amines 6 (Scheme 1)., ${ }^{4,89}$ Cyclic phosphate esters prefer attack at phosphorus by hard nucleophiles, but some examples of ring opening at carbon with soft or bulky nucleophiles have been recognized..$^{10}$ Ko has introduced the cyclic thionocarbonate derivative of a vic-diol, e.g. 7 from diisopropyl tartrate, which undergoes nucleophilic substitution with azide, phenylthiolate and benzoate to give the substituted alcohol $\mathbf{9}$ directly without an acidic hydrolysis step since the intermediate thiocarbonate salt $\mathbf{8}$ loses COS in situ or during aqueous work up (Scheme 2). ${ }^{11}$ The ring $\mathrm{C}-\mathrm{O}$ bond can also be reduced to give malates. ${ }^{12}$ In contrast, cyclic thionocarbonates of tartrate esters react with secondary amines to give enantiopure acyclic thionocarbamates via initial addition to the thione

${ }^{a}$ School of Science and Technology, Nottingham Trent University, Clifton Lane, Nottingham NG11 8NS, U.K. E-mail: john.wallis@ntu.ac.uk

${ }^{b}$ Department of Basic Pharmaceutical Sciences, Faculty of Pharmacy, Hacettepe University, Ankara, Turkey

$\dagger$ CCDC 920882-920888. For crystallographic data in CIF or other electronic format see DOI: 10.1039/c3ra41074a group..$^{13}$ We report here an investigation of the reactions of nucleophiles with five-membered cyclic thionocarbamates, to determine their reactivity and regioselectivity. Cyclic thionocarbamates have been used synthetically in other ways, primarily as chiral auxiliaries, ${ }^{14}$ but also as intermediates in the synthesis of enantiopure protected aryl- $\beta$-hydroxyl- $\alpha$-amino acids $^{15}$ and 1-(Boc)-amino-1-alkenylphosphonate esters, ${ }^{16}$ as derivatives for kinetic resolutions, ${ }^{17}$ as pseudo-C-nucleosides, ${ }^{18}$ in radical reactions, ${ }^{19}$ and as precursors for other oxazolidines. ${ }^{20}$ Carbon disulfide, ${ }^{21}$ thiophosgene ${ }^{18,22}$ or bis(imidazolyl)thione ${ }^{19,20}$ have been used to prepare them from the corresponding aminoalcohols, as well as hydroxyl addition to isothiocyanates ${ }^{18}$ and cycloaddition of aldehydes to anions of substituted methyl isothiocyanates. ${ }^{15,16}$

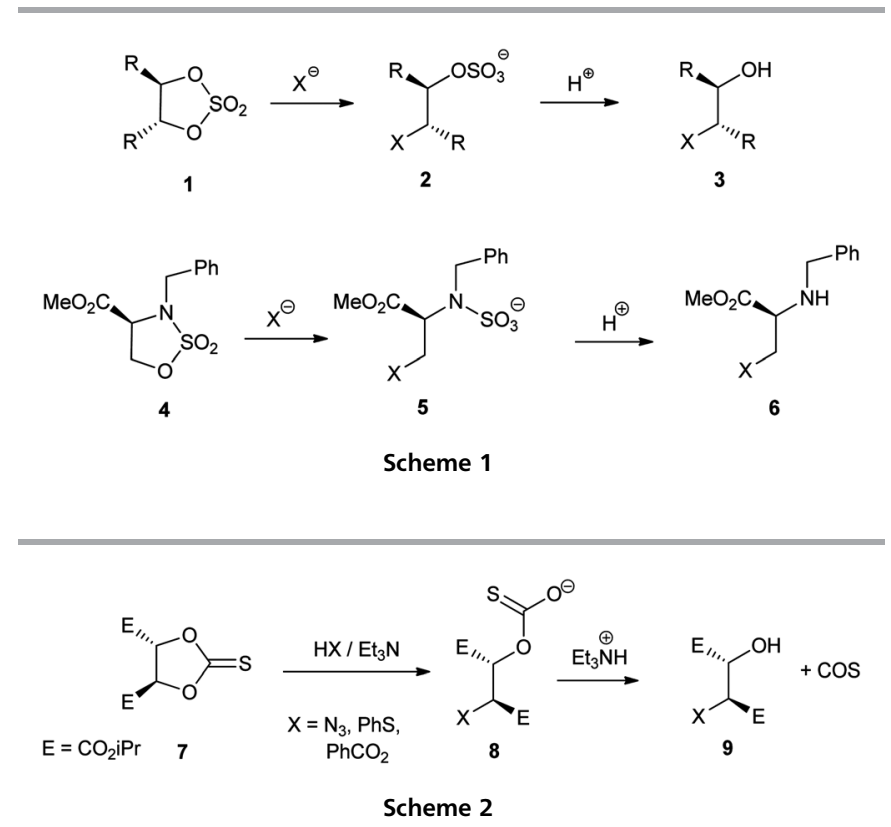




\section{Results and discussion}

$\mathrm{N}$-Benzylalaninol 10 was converted to its cyclic thionocarbamate 11 in 56\% yield by treatment with thiophosgene and pyridine in dichloromethane at $0{ }^{\circ} \mathrm{C}$ (Scheme 3). The reactions of 11 with a variety of nucleophiles under a range of conditions was attempted but none was successful. For example, reactions with sodium thiophenolate, potassium phthalimide and lithiated acetonitrile all showed unreacted starting material even at $60{ }^{\circ} \mathrm{C}$. To understand more about this heterocyclic system the molecular structure was measured by single crystal X-ray diffraction at $120 \mathrm{~K}$.

The structure of $\mathbf{1 1}$ is shown in Fig. 1, with selected molecular geometry in Table 1 . The five-membered ring adopts a

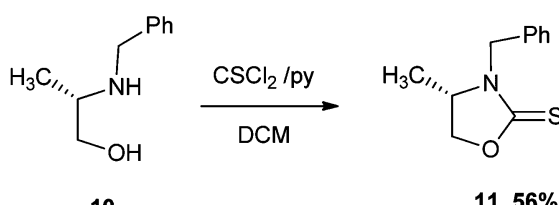

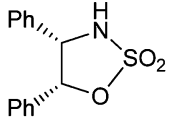

12

Scheme 3

shallow half chair conformation with the two $\mathrm{sp}^{3}$ carbon atoms deviating most from the best ring plane (by 0.073 and $-0.074 \AA$ ). The bonding geometry at nitrogen in $\mathbf{1 1}$ is planar, and it is notable that the bond from nitrogen to the thione carbon $(1.3319(18) \AA)$ is $0.025 \AA$ shorter than that from the oxygen atom (1.3574(17) $\AA$ ) in contrast to the usual trend of bond lengths from these atoms to carbon. A similar trend is observed in the structures of eight low temperature high quality measurements of $\mathrm{N}$-unsubstituted 1,3-oxazolidine-2-thiones in the Cambridge Structural Database ${ }^{23}$ (CSD): N-C: $1.326(8)$, O-C: $1.352(7) \AA^{.24}$ There is thus substantial electron donation of the nitrogen atom's lone pair into the thiocarbonyl group, which is consistent with the longer thiocarbonyl bond in 11 (1.6558(14) $\AA$ ) and the eight other cyclic thionocarbamates (1.658(10) $\AA$ ) compared to those in accurate low temperature measurements of cyclic thionocarbonates (1.623(2)-1.638(2) $\AA$ ). ${ }^{25}$ This strong conjugation from the nitrogen atom suppresses the activating effect of the thione on the ring oxygen atom so that it does not promote its leaving group ability. This is in accord with the $\mathrm{O}-\mathrm{C}(=\mathrm{S})$ bond length in 11 being $0.02 \AA$ longer than in the cyclic thionocarbonates (average 1.331(6) A for three measurements). ${ }^{25}$ In contrast to the cyclic thionocarbamates, the X-ray diffraction
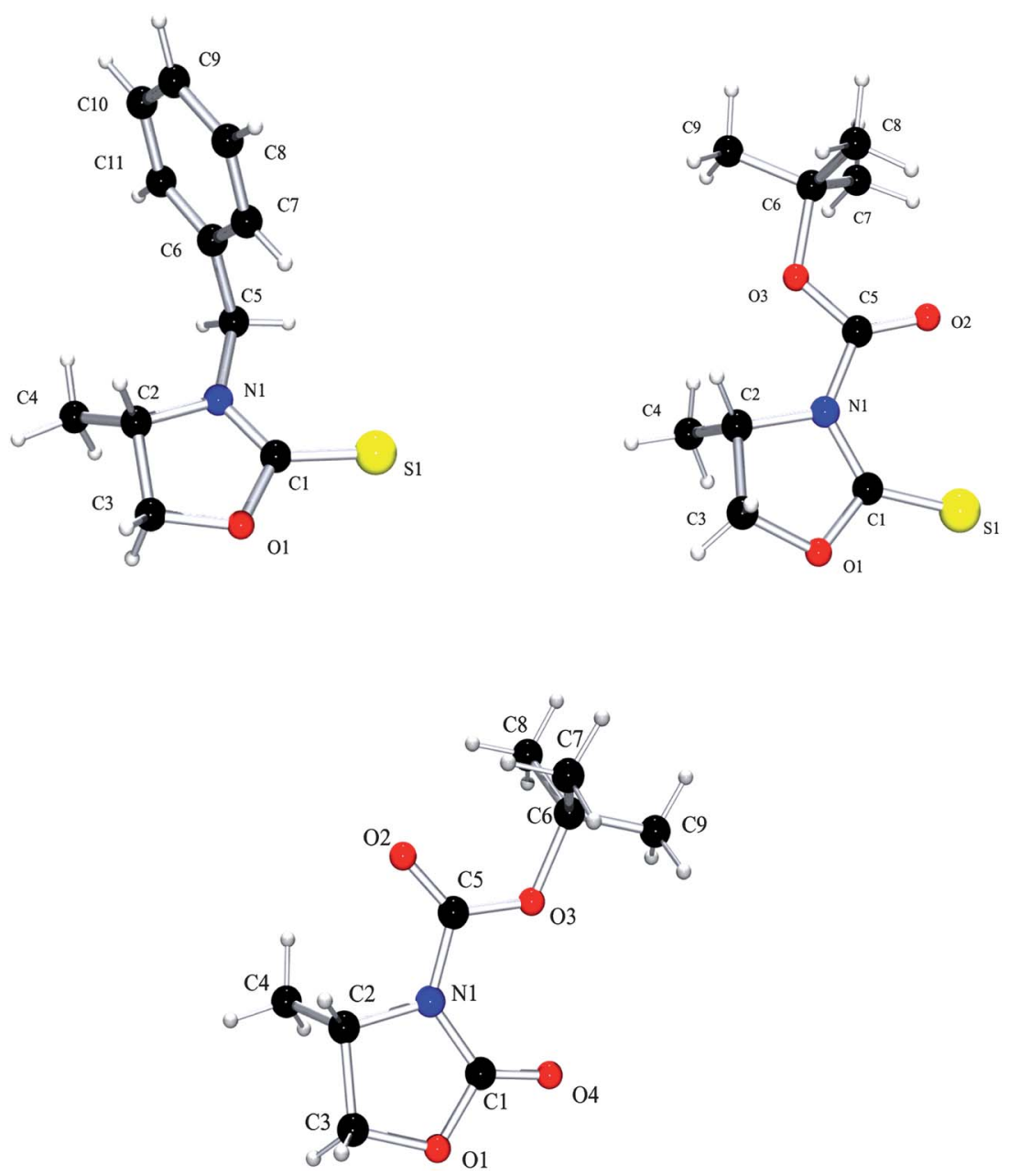

Fig. 1 Molecular structures of $\mathbf{1 1}$ (left), $\mathbf{1 4}$ (right) and $\mathbf{1 7}$ (below) determined by X-ray diffraction. 
Table 1 Selected molecular geometry for molecules 11, 14 and 17, bond lengths in $\AA$, bond angles in 。

\begin{tabular}{llll}
\hline & $\mathbf{1 1}$ & $\mathbf{1 4}$ & $\mathbf{1 7}$ \\
\hline $\mathrm{S} 1=\mathrm{C} 1 / \mathrm{O} 4=\mathrm{C}$ & $1.6558(14)$ & $1.6370(12)$ & $1.1992(19)$ \\
$\mathrm{O} 1-\mathrm{C} 1$ & $1.3574(17)$ & $1.3434(14)$ & $1.348(2)$ \\
$\mathrm{O} 1-\mathrm{C} 3$ & $1.455(2)$ & $1.4637(14)$ & $1.448(2)$ \\
$\mathrm{O} 2-\mathrm{C} 5$ & - & $1.1974(13)$ & $1.206(2)$ \\
$\mathrm{N} 1-\mathrm{C} 1$ & $1.3319(18)$ & $1.3722(14)$ & $1.389(2)$ \\
$\mathrm{N} 1-\mathrm{C} 2$ & $1.4659(17)$ & $1.4860(14)$ & $1.477(2)$ \\
$\mathrm{N} 1-\mathrm{C} 5$ & $1.4625(17)$ & $1.4069(14)$ & $1.400(2)$ \\
$\mathrm{C} 2-\mathrm{C} 3$ & $1.513(2)$ & $1.5180(16)$ & $1.532(2)$ \\
$\mathrm{C} 1-\mathrm{O} 1-\mathrm{C} 3$ & $109.12(11)$ & $109.50(8)$ & $111.28(12)$ \\
$\mathrm{C} 1-\mathrm{N} 1-\mathrm{C} 2$ & $112.75(11)$ & $110.97(9)$ & $112.24(13)$ \\
$\mathrm{C} 1-\mathrm{N} 1-\mathrm{C} 5$ & $124.93(11)$ & $125.74(9)$ & $127.93(13)$ \\
$\mathrm{C} 2-\mathrm{N} 1-\mathrm{C} 5$ & $122.05(11)$ & $123.29(9)$ & $119.12(13)$ \\
N1-C1-S1/N1-C1-O4 & $129.01(10)$ & $130.50(9)$ & $129.36(15)$ \\
N1-C1-O1 & $109.96(12)$ & $108.68(9)$ & $108.75(13)$ \\
O1-C1-S1/O1-C1-O4 & $121.03(10)$ & $120.79(8)$ & $121.88(15)$ \\
N1-C2-C3 & $100.72(12)$ & $99.30(8)$ & $100.94(13)$ \\
O1-C3-C2 & $105.72(12)$ & $103.59(9)$ & $106.25(13)$ \\
& & &
\end{tabular}

studies of the cyclic sulfamidates $4,{ }^{26}$ and $12,{ }^{27}$ show longer bonds from the nitrogen atom to the sulfur atom than from the ring oxygen atom (4: S-N 1.612(2); S-O 1.565(2) $\AA, 12 \mathrm{~S}-\mathrm{N}$ 1.661(2); S-O 1.580(2) $\AA$ ). The interaction of the $\mathrm{N}$ atom with the $\mathrm{SO}_{2}$ group is not sufficient to prevent nucleophilic displacement of the $\mathrm{O}\left(\mathrm{SO}_{2}\right)$ group from the $5-\mathrm{C}$ atom.

To reduce the delocalisation of electron density from the nitrogen atom the $N$-Boc cyclic thionocarbamates of alaninol and serine methyl ester $\mathbf{1 4}$ and $\mathbf{1 6}$ were prepared in two steps, first forming the cyclic thionocarbamates $\mathbf{1 3}$ and $\mathbf{1 5}$ by reaction with thiophosgene and triethylamine, and then reaction with di-tertbutyl dicarbonate, pyridine and 4-dimethylaminopyridine to give the final products as recently described by one of us (Scheme 4). ${ }^{28}$ The structure of 14 was measured by X-ray diffraction at $120 \mathrm{~K}$, and the results are shown in Fig. 1 and in Table 1.

The heterocyclic ring of the cyclic thionocarbamate $\mathbf{1 4}$ adopts an approximate half chair conformation, significantly more puckered than in $\mathbf{1 1}$, with the ring $\mathrm{sp}^{3}$ carbon atoms
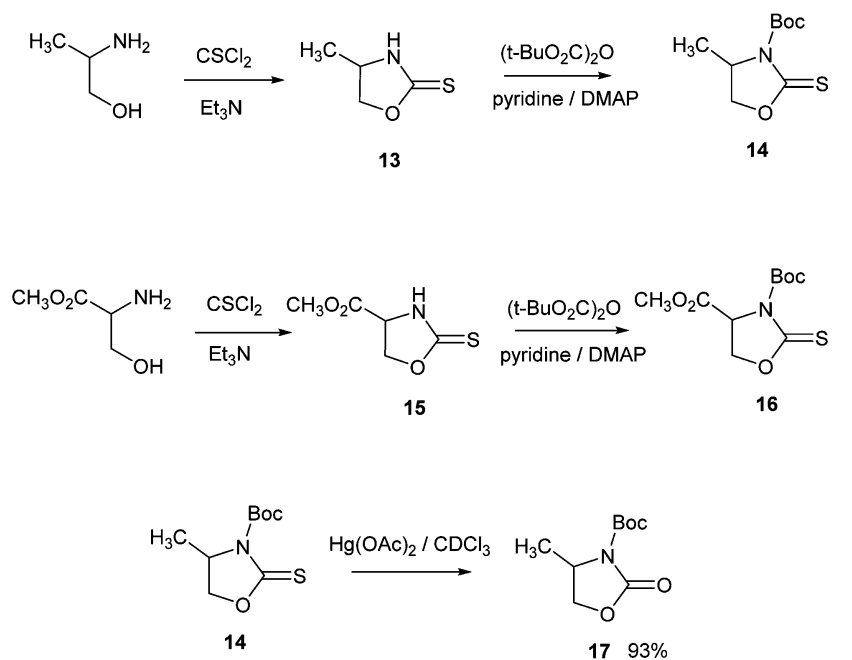

Scheme 4 deviating most from the ring's best plane (by 0.154 and $-0.164 \AA$ ). The bonding at the nitrogen atom is planar and the Boc group is well aligned for conjugation with the ring nitrogen, with torsion angles about the $\mathrm{N}-\mathrm{C}(\mathrm{Boc})$ bond of 7.67(18) and 8.04(14) $)^{\circ}$. In contrast to $\mathbf{1 1}$ the ring bond from nitrogen to the thiocarbonyl group $(1.3722(14) \AA)$ is longer than the ring bond from oxygen to the thiocarbonyl group $(1.3464(14) \AA)$. There is clear evidence of less electron delocalization from the nitrogen atom into the thione bond than in the $\mathrm{N}$-benzyl derivative $\mathbf{1 1}$ from the longer $\mathrm{N}-\mathrm{C}(=\mathrm{S})$ bond (by $0.040 \AA$ ) and the shorter thiocarbonyl bond (by $0.019 \AA$ ) in 14. There is a small contraction in the $\mathrm{O}-\mathrm{C}(=\mathrm{S})$ bond (by $0.014 \AA$ ), signifying an increase in the electron delocalization from oxygen into the thiocarbonyl group. However, conjugation of nitrogen with the thione group is not eliminated in 14; the bond from the nitrogen to the thione group is still shorter than that to the Boc group (by $0.035 \AA$ ), and the latter (1.4069(14) $\AA$ ) is notably longer (by $c a$. $0.05 \AA$ ) than in $N$-Boc compounds which do not carry a second electron attracting group e.g. carrying two sp ${ }^{3}$ carbons for which $\mathrm{C}-\mathrm{N}$ : $1.357(12) \AA$ (168 examples measured at $T<150 \mathrm{~K}$ ). ${ }^{23}$ The structures of three oxazolidine-2-thiones bearing $N$-acyl substituents have been reported, and all show the exocyclic $\mathrm{N}-\mathrm{C}$ bond to be longer than the endocyclic one. ${ }^{29}$ The corresponding structure where the thione is replaced by a carbonyl group, 17, prepared from $\mathbf{1 4}$ with mercuric acetate, was also determined (Fig. 1) and shows a longer endocyclic $\mathrm{N}-\mathrm{C}$ bond $(1.389(2) \AA)$ than 14, consistent with slightly better conjugation of nitrogen with a thione than with a carbonyl group.

Reactions of cyclic thionocarbamates 14 and 16 with several nucleophiles have been investigated and, in contrast to the $N$ benzyl derivative 11, some successful ring openings at 5-C observed (Scheme 5). Thus, 14 reacted with sodium pyridine-2thiolate in THF at $60{ }^{\circ} \mathrm{C}$ to give the substituted $N$-Boc amine 19 $(60 \%)$ accompanied by a small amount of the corresponding $N, N$ diBoc analogue $20(6 \%)$. The reaction proceeds by ring opening of 14 by the nucleophile at 5-C followed by loss of COS leading to anion 18 which is then protonated in the work up to give the major product. Presumably, a small amount of anion 18 abstracts a Boc group from starting material to give the diBoc material 20. Some unactivated thionocarbamate $\mathbf{1 3}$ was also isolated. Sodium phenylthiolate reacted with $\mathbf{1 4}$ under similar conditions, giving the ring-opened product $\mathbf{2 2}$ (32\%), a small amount of the corresponding diBoc compound $\mathbf{2 3}(4 \%)$ and a significant yield of the 1,3,5-triazinetrione derivative 24 (38\%). The latter may be formed by the reaction of initially formed anion 21 with the isocyanate $\mathbf{2 5}$ derived from further $\mathbf{2 1}$ by loss of $t$-butoxide. Trimersations of isocyanates catalysed by nucleophiles are known. ${ }^{30}$ Sodium ethanethiolate reacted with $\mathbf{1 4}$ to give the ring opened product $\mathbf{2 6}$ in $25 \%$ yield at room temperature, but under microwave conditions in xylene $\left(145^{\circ} \mathrm{C}\right)$ the yield rose to $58 \% .14$ also reacted with potassium thioacetate in DMF at $20^{\circ} \mathrm{C}$ to give the ring opened product 28 in which the sulfur carries the Boc group and the nitrogen carries the acetate. Ring opening gives the anion 27 which then abstracts the acetyl group from the sulfur to leave a thiolate which abstracts the Boc group from nitrogen (Scheme 6). The structural assignment is supported by IR and NMR data. The ${ }^{13} \mathrm{C}$ signals for the carbonyl carbons are observed at $\delta_{\mathrm{c}}: 169.5$ 


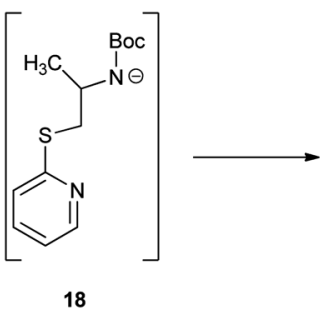<smiles>CC(CSc1ccccn1)NC(=O)OC(C)(C)C(=O)OC(C)(C)C(=O)OC(C)(C)C(=O)OC(C)(C)C</smiles><smiles>CC1COC(=S)N1C(=O)OCc1ccccc1</smiles>

14

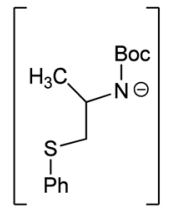

21<smiles>CC(CSc1ccccc1)[N+](=O)[O-]</smiles>

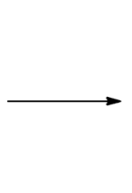<smiles>CC(CSPc1ccccc1)NC(=O)OCc1ccccc1</smiles>

$2232 \%$<smiles>CC(CSc1ccccc1)N(C(=O)OCc1ccccc1)C(=O)OC(C)(C)C</smiles>

$234 \%$<smiles>CC(CSc1ccccc1)n1c(=O)n(C(C)Cc2ccccc2)c(=O)n(C(C)Cc2ccccc2)c1=O</smiles>

Scheme 5
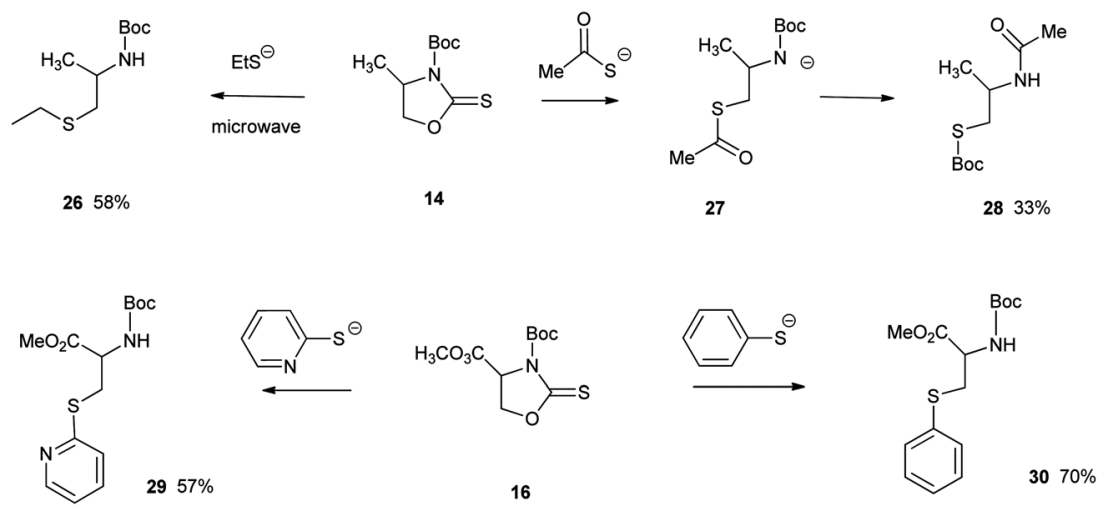

Scheme 6

(S- $C=\mathrm{O})$ and $159.8(\mathrm{~N}-C=\mathrm{O})$ while a $S$-acetyl carbonyl C would be observed at $c a . \delta_{\mathrm{c}}: 195(\mathrm{~S}-\mathrm{C}=\mathrm{O})$. Furthermore, the infrared absorption at $1645 \mathrm{~cm}^{-1}$ is only compatible with an amide and not with a $N$-Boc group (expected $c a .1680 \mathrm{~cm}^{-1}$ ). Cyclic thionocarbamate 16 also undergoes ring opening with sodium 2pyridinethiolate and phenylthiolate to give the $\mathrm{N}$-Boc protected esters 29 and 30 in yields of 57\% and 70\% (Scheme 6).

The reaction of $\mathbf{1 4}$ with iodide was also investigated since ring opening at 5-C by iodide could be followed by an intramolecular substitution of iodide by the thiocarbamate anion via sulfur to give thiazolidin-2-one $\mathbf{3 1}$ (Scheme 7). Thionocarbonates such as 7 are known to undergo the corresponding reaction with the bromide ion. ${ }^{11 a}$ Reaction of $\mathbf{1 4}$ with tetrabutylammonium iodide in THF or toluene under refluxing conditions was unsuccessful, but transferring the reaction to microwave conditions in xylene at $145{ }^{\circ} \mathrm{C}$ gave a $57 \%$ yield of the thiazolidin-2-one 31 , the structure of which was confirmed by a crystal structure determination (Fig. 2). Compound $\mathbf{3 1}$ is a potential precursor to vicaminothiols, which are useful heterocyclic building blocks, linkers and ligands. ${ }^{31}$ In the crystal structure of $\mathbf{3 1}$ the ring system adopts an approximate envelope conformation with the methine carbon lying $0.51 \AA$ out of the plane of the other four atoms. The bond lengths from nitrogen to the ring and Boc carbonyls are similar: 1.391(3) and 1.403(3) Å respectively.

Given the success of the above rearrangement reaction with iodide, the reaction was attempted with the unactivated cyclic 
<smiles>CC1COC(=S)N1C(=O)c1ccccc1</smiles>

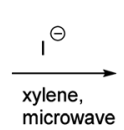<smiles>CCOC(=O)N(C(=O)c1ccccc1)C(C)CI</smiles><smiles>CC1CSC(=O)N1C(=O)OCc1ccccc1</smiles>

14

$$
\left.\sum_{\mathrm{S}}^{\mathrm{N}}=\mathrm{O} \underset{\substack{\text { xylene, } \\ \text { microwave }}}{\mathrm{1}^{\Theta}} \mathrm{O}_{\mathrm{O}}^{\mathrm{H} \mathrm{C}}\right\rangle_{\mathrm{S}}^{\mathrm{H}}
$$

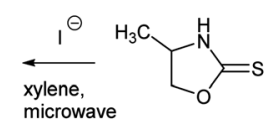

$3295 \%$

13
Scheme 7

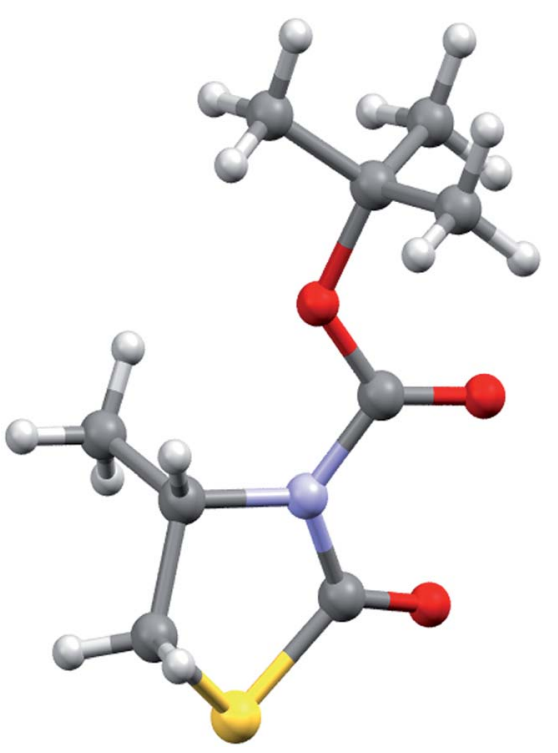

Fig. 2 Molecular structure of $\mathbf{3 1}$ determined by X-ray diffraction.

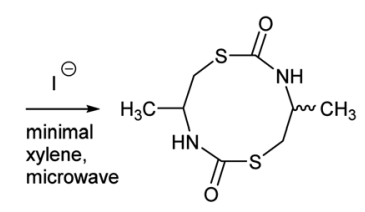

$3328 \%$

$3157 \%$

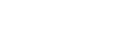

addition to the thione followed by collapse of the tetrahedral intermediate 43 with breakage of the ring $\mathrm{C}-\mathrm{N}$ bond to give 34-37 in yields of 46, 53, 95 and 32\% respectively, 35 being obtained as a $1: 1$ mixture of diastereomers. The high yield of 36 reflects the known high reactivity of $t$-butyl organometallics, and addition to the thione in this case may go via a single electron transfer mechanism (Scheme 8). It was important to exclude the isomeric structural assignments of these products as alcohols of type 39 which would be formed by breaking the ring $\mathrm{C}-\mathrm{O}$ bond rather than the ring $\mathrm{C}-\mathrm{N}$ bond. Examination of the literature suggested that there was no clearly ambiguous spectroscopic method for this, for example based on the infrared stretch of the $\mathrm{C}=\mathrm{S}$ group or on the ${ }^{13} \mathrm{C}$ chemical shift of the thione carbon atom, so the structures of 36 and 37 were determined by X-ray crystallography (Fig. 3).

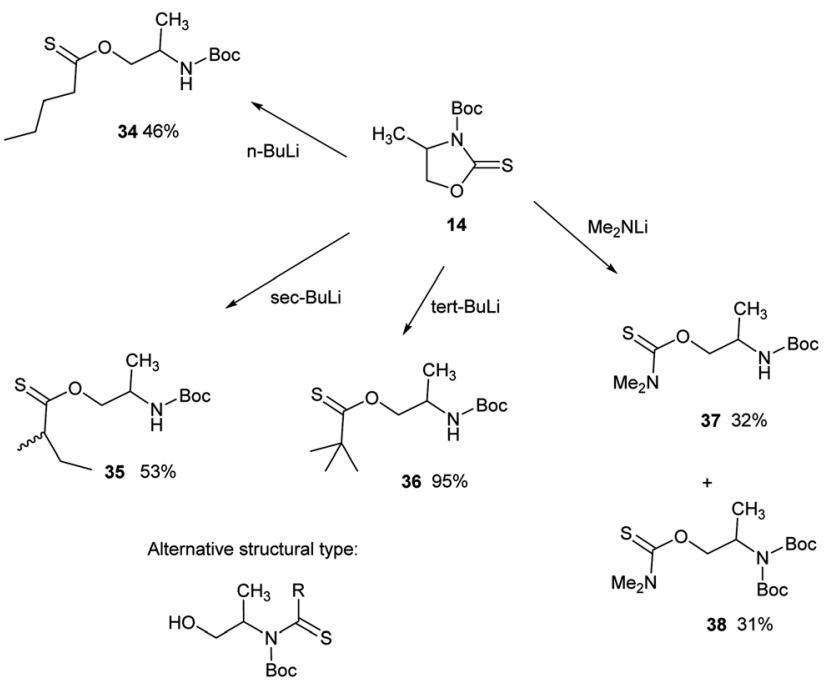

$39 \quad \mathbf{R}=\mathbf{n}-\mathrm{Bu}, \mathrm{t}-\mathrm{Bu}, \mathrm{NMe}_{2}$

Scheme 8

thionocarbamate, which did not carry a Boc group on the ring nitrogen 13. Under microwave conditions in xylene $\left(145^{\circ} \mathrm{C}\right.$, one hour) the reaction is indeed successful providing the thiazolidinone 32 in 95\% yield. However, when the reaction was carried out in almost solvent free conditions, the dimeric product $\mathbf{3 3}$ was isolated in $27 \%$ yield which has been formed by reaction between two molecules of the initial product of ring opening with iodide. Thus under forcing conditions even the unactivated system 13 will undergo reaction with iodide.

Given the presence of thione and urethane functionalities in molecule $\mathbf{1 4}$ we were interested to see how "harder" nucleophiles selected between attack at these groups and attack at the ring 5-C atom. Thus, reaction with a range of organolithium and organomagnesium nucleophiles were investigated which unveiled a rather selective and interesting chemistry, leading to unusual products in some cases. The reaction of $\mathbf{1 4}$ with these "harder" nucleophiles all start by attack of the organometallic on the thione group to give $\mathbf{4 3}$ but the precise product produced depends on the subsequent reactions of this addition product (Scheme 10). Thus, $n$-butyl lithium, sec-butyl lithium, $t$-butyl lithium and lithium dimethylamide react with 14 at $-78{ }^{\circ} \mathrm{C}$ by
Fig. 3 Molecular structure of $\mathbf{3 6}$ (above) and $\mathbf{3 7}$ (below) determined by X-ray diffraction. The conformations differ by a rotation about the central $\mathrm{CH}-\mathrm{CH}_{2}$ bond. 
The adduct 37 from the reaction of thionocarbamate 14 with lithium dimethylamide was accompanied by a significant yield of 38 the corresponding compound which carried an extra Boc group on the nitrogen atom, the structure of which was also confirmed by X-ray crystallography. This material has probably arisen by the anion formed on ring cleavage then removing a Boc group from starting material 14.

The structures of 36-38 were measured at $150 \mathrm{~K}$ (Fig. 3 and 4), and for 36 there were two independent molecules in the asymmetric unit. All molecules show a planar arrangement involving the thiocarbonyl group and the attached oxygen and carbon or nitrogen atoms. For the two thiourethanes 37 and 38 the thiocarbonyl group is much longer $(1.6710(15) \& 1.6788(15) \AA)$ than for the two molecules of thionoester 36 (1.602(3) and 1.629(3) A) due to the strong conjugation of nitrogen with the thione group. The $\mathrm{O}-\mathrm{C}(=\mathrm{S})$ bond in thionoester $36(1.327(3)$ and 1.315(4) $\AA$ ) is significantly shorter than in the thiourethanes $(1.3408(17)$ and 1.3415(17) ̊) since there is no competition for conjugation with the thione group. In the compound 38 which has two Boc groups attached to the nitrogen atom, the two carbonyl groups are directed away from each other but there is a short 1,5 contact between the butoxy $\mathrm{O}$ atoms of just $2.545 \AA$ A. The bonding geometry at the nitrogen and the two carbonyl carbons are all planar, but one of the Boc group has twisted about its $\mathrm{N}-\mathrm{C}$ bond by $\mathrm{ca} .32^{\circ}$ to maximise the $\mathrm{O} \cdots \mathrm{O}$ separation. The structure of $\mathbf{3 4}$, a liquid at room temperature, is supported by comparison of spectral data with those 36. The O-methylene group has a chemical shift of $\delta_{\mathrm{c}}$ : $74.3 \mathrm{ppm}$ very close to that of $36\left(\delta_{\mathrm{c}}: 74.8 \mathrm{ppm}\right)$, whereas the alternative structure $39(R=n-\mathrm{Bu})$ would be expected to have a lower shift for its $-\mathrm{CH}_{2} \mathrm{OH}$ group. The thione group for $\mathbf{3 4}$ shows a stretching frequency of $1175 \mathrm{~cm}^{-1}$ and ${ }^{13} \mathrm{C}$ chemical shift of 224.2 ppm similar to the values for 36 of $1163 \mathrm{~cm}^{-1}$ and $\delta_{\mathrm{c}}: 231 \mathrm{ppm}$.

Interestingly, the reaction of $\mathbf{1 4}$ with phenyl lithium led to a different type of product i.e. the thiazoline 40 in $95 \%$ yield, which was also obtained by reaction with phenyl magnesium bromide in $38 \%$. Reaction with phenylethynyl lithium gave the corresponding thiazoline product, the disubstituted alkyne, $\mathbf{4 1}$ in 59\% yield (Scheme 9). The structural assignment is supported by ${ }^{13} \mathrm{C}$ resonance of the $4-\mathrm{C}$ at $\delta_{\mathrm{c}}$ : 72.7 similar to that shown for a series of closely related thiazolines. ${ }^{32}$ In contrast,

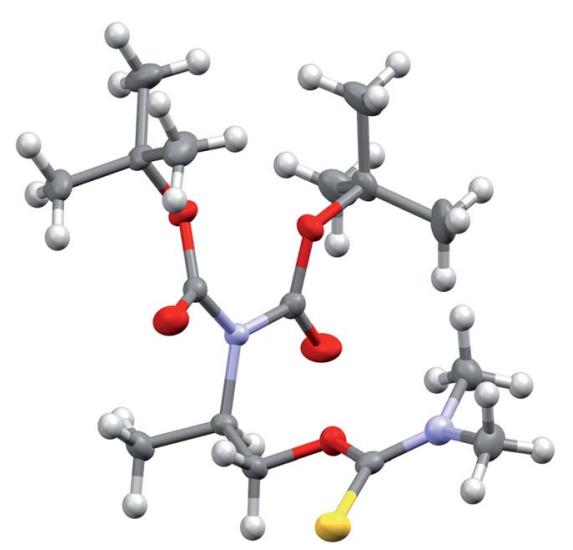

Fig. 4 Molecular structure of $\mathbf{3 8}$ determined by X-ray diffraction, showing the mutual arrangement of the two Boc groups on the nitrogen atom.

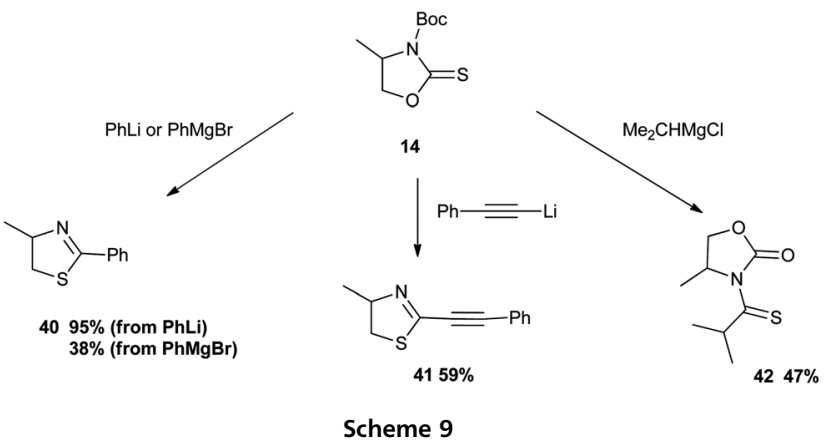

reaction of $\mathbf{1 4}$ with isopropyl magnesium chloride gave the oxazolidinone 42 in $47 \%$ yield. These products arise from initial addition of the organometallic reagent to the thione to give $\mathbf{4 3}$ and subsequent ring opening by ring $\mathrm{O}-\mathrm{C}$ bond cleavage, rather than $\mathrm{N}-\mathrm{C}$ bond cleavage, followed by attack of the oxyanion on the Boc carbonyl group to give a five-membered ring as an intermediate anion. In the case of the thiazolines, the Boc group is transferred to oxygen making the latter a good leaving group which is displaced by the thioamide anion to form the ring system (Scheme 10). In the case of the oxazolidinone the attack of the oxyanion on the Boc group is followed by expulsion of the butoxide ion. All processes following the attack on the thiocarbonyl group may well be reversible, with the exception of the loss of $t-\mathrm{BuO}_{2} \mathrm{CO}$ to give the thiazolines, which may be favoured by groups which conjugate with the thioamide anion. In contrast, phenyl lithium reacts with the ester substituted thionocarbamate 16 to give the alkene 44, formed by initial deprotonation next to the ester group, and the phenyl substituted material 45 (Scheme 11).

In summary, sulfur centred 'soft' nucleophiles attack the cyclic thionocarbamate by ring-opening at 5-C followed by loss

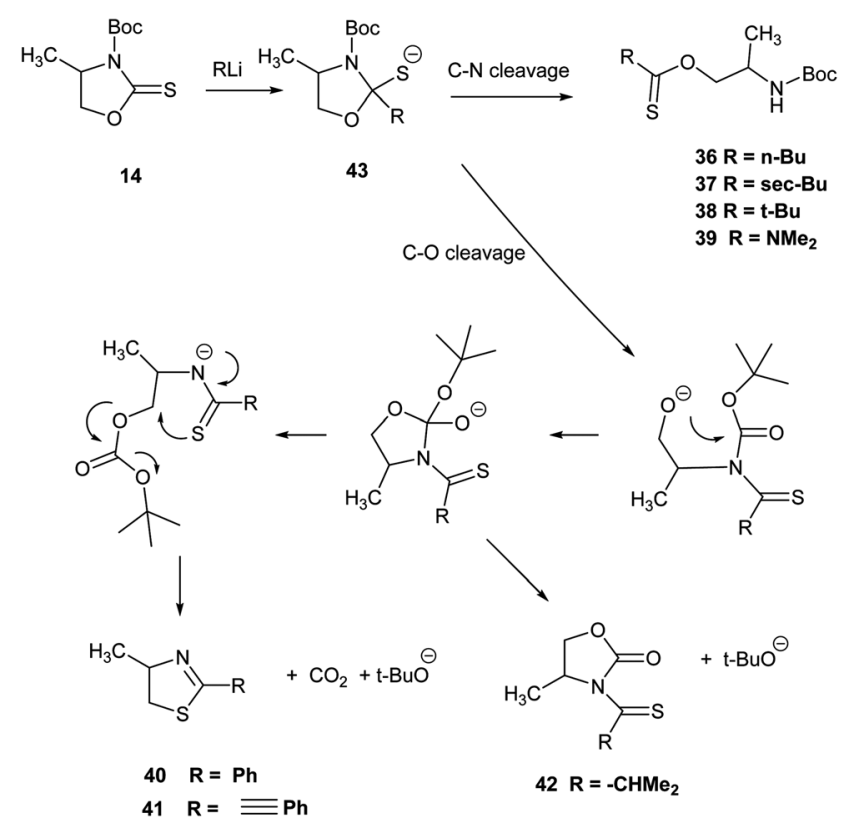

Scheme 10 


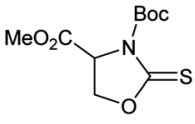

16

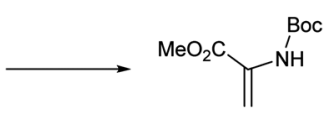

$4452 \%$

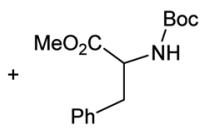

$4529 \%$
Scheme 11

of COS to give beta-substituted $N$-Boc amines, including a vicaminothiol derivative via the reaction with iodide, while 'hard' organolithium and Grignard reagents give a variety of unusual products which are all derived from attack on the thione group. The former has potential applications to the preparation of novel chiral ligands for metal binding and catalysis, while the latter provides access to new derivatives of heterocyclic systems.

\section{Experimental}

\section{General}

NMR spectra were measured on a JEOL JNM-EX270 spectrometer at $270 \mathrm{MHz}$ for ${ }^{1} \mathrm{H}$ and at $67.8 \mathrm{MHz}$ for ${ }^{13} \mathrm{C}$ or on a JEOL ECLIPSE 400 spectrometer at $400 \mathrm{MHz}$ for ${ }^{1} \mathrm{H}$ and at $100 \mathrm{MHz}$ for ${ }^{13} \mathrm{C}$ using $\mathrm{CDCl}_{3}$ as solvent, and measured in ppm downfield from TMS, unless otherwise stated. IR spectra were recorded on Perkin Elmer Spectrum 100 FT-IR Spectrometer using an ATR window, and are reported in $\mathrm{cm}^{-1}$. Mass spectra were recorded at the EPSRC Mass Spectrometry Centre at Swansea University. Melting points were recorded on a Stuart SMP30 melting point apparatus. Chemical analysis data were obtained from Mr Stephen Boyer, London Metropolitan University. Optical rotations were measured on a Perkin Elmer 241 polarimeter at $21^{\circ} \mathrm{C}$ using sodium D line radiation and are reported in $10^{-1} \mathrm{deg} . \mathrm{cm}^{2} \mathrm{~g}^{-1}$. Flash chromatography was performed on 40-63 silica gel (Merck). Microwave experiments were carried out in CEM Discover SP synthesis system.

\section{Preparation of 11}

Thiophosgene (3.48 g, $2.31 \mathrm{ml}, 30.3 \mathrm{mmol}$ ) in dichloromethane $(15 \mathrm{ml})$ was added dropwise to a stirred solution of dry pyridine (4.82 g, $60.1 \mathrm{mmol}$ ) and $S$-2-benzylaminopropanol (5.00 g, 30.3 $\mathrm{mmol})$ in dichloromethane $(50 \mathrm{ml})$ at $0{ }^{\circ} \mathrm{C}$ under nitrogen. The mixture was stirred at $0{ }^{\circ} \mathrm{C}$ for $3 \mathrm{~h}$. and left to warm up to room temperature overnight. Water $(50 \mathrm{ml})$ was added and the organic layer separated and washed with hydrochloric acid $(1 \mathrm{M}, 2 \times 30 \mathrm{ml})$ and brine. After drying over sodium sulfate, the organic extract was evaporated to give a brown oil which was purified by chromatography using hexane-ethyl acetate $(1: 1)$ as eluent to furnish $S$-3-benzyl-4-methyl-1,3-oxazolidine-2-thione $(3.50 \mathrm{~g}, 55.8 \%)$ as a clear oil which slowly crystallised, m.p. 77-79 ${ }^{\circ}$ C. Anal. calcd for $\mathrm{C}_{11} \mathrm{H}_{13} \mathrm{NSO}$ : C: $63.7, \mathrm{H}: 6.3$, N: $6.8 \%$, found $\mathrm{C}: 63.8, \mathrm{H}: 6.4, \mathrm{~N}: 6.7 \% ; \delta_{\mathrm{H}}\left(400 \mathrm{MHz} \mathrm{CDCl}_{3}\right): 7.22-7.35$ $\left(5 \mathrm{H}, \mathrm{m}, \mathrm{Ar}-H_{5}\right), 5.38\left(1 \mathrm{H}, \mathrm{d}, J=15.1 \mathrm{~Hz}, \mathrm{PhCH}_{\alpha}\right), 4.53(1 \mathrm{H}, \mathrm{t}, J=$ $\left.8.8 \mathrm{~Hz}, 5 H_{\alpha}\right), 4.34\left(1 \mathrm{H}, \mathrm{d}, J=15.1 \mathrm{~Hz}, \mathrm{PhCH}_{\beta}\right), 4.03(1 \mathrm{H}, \mathrm{dd}, J=$ 8.8, 7.4 Hz, 5- $\left.H_{\beta}\right), 3.79-3.92(1 \mathrm{H}, \mathrm{m}, 4-H), 1.25(3 \mathrm{H}, \mathrm{d}, J=6.4 \mathrm{~Hz}$, $\left.4-\mathrm{CH}_{3}\right) ; \delta_{\mathrm{C}}:\left(100 \mathrm{MHz}, \mathrm{CDCl}_{3}\right): 188.0(2-\mathrm{C}), 134.6,128.8,128.0$ and $127.9\left(\mathrm{Ar}-C_{6}\right), 72.7(5-C), 53.9(4-C), 49.1\left(\mathrm{~N}-C_{2}\right), 17.5$ $\left(\mathrm{CH}_{3}\right)$; $\nu_{\max }: 1583,1481,1450,1431,1348,1306,1285,1235$,
1200, 1142, 1114, 1078, 1061, 1030, 984, 968, 911, 873, 852, 817, 806, 769, 725, 700, 675, 664, $585 \mathrm{~cm}^{-1}$; m/z: (EI) $207\left(\mathrm{M}^{+}\right), 132$, $91 ;[\alpha]_{\mathrm{D}}=-161^{\circ}\left(c=0.5\right.$ in $\left.\mathrm{CH}_{2} \mathrm{Cl}_{2}\right)$.

\section{Preparation of 13}

A solution of thiophosgene $(2.0 \mathrm{ml}, 25.6 \mathrm{mmol})$ in dichloromethane $(2 \mathrm{ml})$ was added dropwise to a solution of 2-amino-1propanol (1.93 g, $2.0 \mathrm{ml}, 25.6 \mathrm{mmol})$ and triethylamine $(6.51 \mathrm{~g}$, $9.0 \mathrm{ml}, 64.4 \mathrm{mmol})$ in dry dichloromethane $(50 \mathrm{ml})$ at $0{ }^{\circ} \mathrm{C}$, and stirred for $3 \mathrm{~h}$ at room temperature. The reaction was quenched with $10 \% \mathrm{HCl}$, the organic layer separated and the aqueous layer extracted with dichloromethane $(2 \times 40 \mathrm{ml})$. The combined organic fractions were washed with water $(40 \mathrm{ml})$ and dried over $\mathrm{Na}_{2} \mathrm{SO}_{4}$. The crude material was purified by chromatography using cyclohexane-ethyl acetate $(1: 1)$ as eluent to provide 4-methyloxazolidine-2-thione $\mathbf{1 3}^{33}$ as a yellow solid (1.09 g, 36\%), m.p. $76-78{ }^{\circ} \mathrm{C}$; $\delta_{\mathrm{H}}\left(400 \mathrm{MHz}, \mathrm{CDCl}_{3}\right): 8.21$ (1H, br-s, $\mathrm{NH}), 4.66-4.74\left(1 \mathrm{H}, \mathrm{m}, 5-\mathrm{CH}_{\alpha}\right), 4.13-4.20\left(2 \mathrm{H}, \mathrm{m}, 4-\mathrm{H}, 5-\mathrm{CH}_{\beta}\right)$, $1.30\left(3 \mathrm{H}, \mathrm{d}, J=5.8 \mathrm{~Hz}, \mathrm{CH}_{3}\right) ; \delta_{\mathrm{C}}\left(400 \mathrm{MHz}, \mathrm{CDCl}_{3}\right): 189.0(2-C)$, 76.8 (5-C), 52.5 (4-C), $19.9\left(\mathrm{CH}_{3}\right)$; $\nu_{\max }$ : 3168, 3021, 1646, 1532, 1181; m/z: (EI) $117\left(\mathrm{M}^{+}\right), 102,86,42 ; H R M S$ : (EI) for $[\mathrm{M}+\mathrm{H}]^{+}$ $\mathrm{C}_{4} \mathrm{H}_{8} \mathrm{NOS}$ requires 118.0321 , found: 118.0320 .

\section{Preparation of 14}

4-(Dimethylamino)pyridine $(0.64 \mathrm{~g}, 5.16 \mathrm{mmol})$ in dichloromethane $(18 \mathrm{ml})$ was added dropwise to a solution of $\mathbf{1 3}$ (6.00 g, $51.6 \mathrm{mmol})$, triethylamine $(5.20 \mathrm{~g}, 50.6 \mathrm{mmol})$ and di-t-butyl dicarbonate $(11.6 \mathrm{~g}, 51.6 \mathrm{mmol})$ in dichloromethane $(120 \mathrm{ml})$ under nitrogen at $0{ }^{\circ} \mathrm{C}$. The solution was stirred at room temperature for $7 \mathrm{~h}$. The volatilities were removed and residue was purified by chromatography using hexane-ethyl acetate (2:1) as eluent to give 3-t-butyloxycarbonyl-4-methyl-oxazolidine2-thione 14 as a yellow solid (4.80 g, 44\%). m.p. $102-103{ }^{\circ} \mathrm{C}$. Anal. calcd for $\mathrm{C}_{9} \mathrm{H}_{15} \mathrm{NO}_{3} \mathrm{~S}: \mathrm{C}, 49.75 ; \mathrm{H}, 6.96 ; \mathrm{N}, 6.45$, S: $14.76 \%$; found: $\mathrm{C}, 50.01 ; \mathrm{H}, 6.71 ; \mathrm{N}, 6.36, \mathrm{~S}: 14.35 \% ; \delta_{\mathrm{H}}(400 \mathrm{MHz}$, $\left.\mathrm{CDCl}_{3}\right)$ : 4.49-4.58 (1H, m, 4- $\left.H\right), 4.47\left(1 \mathrm{H}, \mathrm{t}, J=7.8 \mathrm{~Hz}, 5-H_{\alpha}\right), 4.08$ $\left(1 \mathrm{H}, \mathrm{dd}, J=8.4,3.0 \mathrm{~Hz}, 5-H_{\beta}\right), 1.50\left(9 \mathrm{H}, \mathrm{s}, 3 \times \mathrm{CH}_{3}\right), 1.38(3 \mathrm{H}, \mathrm{d}$, $\left.J=6.2 \mathrm{~Hz}, 4-\mathrm{CH}_{3}\right) ; \delta_{\mathrm{C}}\left(400 \mathrm{MHz}, \mathrm{CDCl}_{3}\right): 184.4(C=\mathrm{S}), 149.3$ $(\mathrm{N}-\mathrm{C}=\mathrm{O}), 84.8\left(\mathrm{C}\left(\mathrm{CH}_{3}\right)_{3}\right), 72.9(5-\mathrm{C}), 55.4(4-\mathrm{C}), 28.0\left(3 \times \mathrm{CH}_{3}\right)$, $19.3\left(4-\mathrm{CH}_{3}\right)$; $\nu_{\max }: 2986,2930,1759,1157 ; \mathrm{m} / \mathrm{z}:(\mathrm{ESI}) 240([\mathrm{M}+$ $\left.\mathrm{Na}]^{+}\right), 162$.

\section{Preparation of 15}

Triethylamine $(9.94 \mathrm{~g}, 98.4 \mathrm{mmol})$ was added to a stirring solution of DL-serine methyl ester hydrochloride $(5.00 \mathrm{~g}$, $32.8 \mathrm{mmol})$ in dichloromethane $(50 \mathrm{ml})$ under nitrogen at $0{ }^{\circ} \mathrm{C}$. Thiophosgene $(3.77 \mathrm{~g}, 2.52 \mathrm{ml}, 32.8 \mathrm{mmol})$ in dichloromethane $(15 \mathrm{ml})$ was added dropwise and the resulting mixture was allowed to stir at $0{ }^{\circ} \mathrm{C}$ for $3 \mathrm{~h}$ gradually warming to room temperature overnight. Water was added to the mixture. The organic layer was separated and washed with $1 \mathrm{M}$ hydrochloric acid $(2 \times 30 \mathrm{ml})$ and brine $(50 \mathrm{ml})$ and dried over sodium sulphate. Final purification was achieved by column chromatography with ethyl acetate-dichloromethane $(1: 5)$ as eluent to give methyl 2-thioxooxazolidine-4-carboxylate 15 (3.50 g, 66\%) as a colourless oil. Anal. calcd for $\mathrm{C}_{5} \mathrm{H}_{7} \mathrm{NO}_{3} \mathrm{~S}$ : C, 37.26, $\mathrm{H}, 4.38, \mathrm{~N}$ : 
8.69\%, found: C, 37.60, $\mathrm{H}: 4.31, \mathrm{~N}: 8.43 \% ; \delta_{\mathrm{H}}\left(270 \mathrm{MHz}, \mathrm{CDCl}_{3}\right)$ : 8.27 (1H, br-s, N-H), 4.62-4.90 (3H, m, 4- H, 5- $\left.H_{2}\right), 3.85(3 \mathrm{H}, \mathrm{s}$, $\left.\mathrm{OCH}_{3}\right) ; \delta_{\mathrm{C}}\left(400 \mathrm{MHz}, \mathrm{CDCl}_{3}\right): 189.7(\mathrm{C}=\mathrm{S}), 169.4(\mathrm{C}=\mathrm{O}), 72.4(5-$ $C)$, $57.4(4-C), 53.5\left(\mathrm{OCH}_{3}\right)$; $\nu_{\max }: 3315,2960,1745,1602,1509$, 1361, 1265, 1178, 1101, 1037, 958; m/z: (CI) $179\left(\left[\mathrm{M}+\mathrm{NH}_{4}\right]^{+}\right), 162$ $\left([\mathrm{M}+\mathrm{H}]^{+}\right), 147,130$.

\section{Preparation of 16}

Triethylamine (4.32 g, $42.6 \mathrm{mmol})$, di-t-butyl dicarbonate (18.77 g, $85.2 \mathrm{mmol}$ ) and 4-dimethylaminopyridine (0.52 g, 4.28 $\mathrm{mmol})$ were added to a stirred solution of $\mathbf{1 5}$ (6.86 g, $42.6 \mathrm{mmol})$ in dichloromethane $(80 \mathrm{ml})$ under nitrogen at $25{ }^{\circ} \mathrm{C}$ and the mixture stirred for $7 \mathrm{~h}$. The mixture was evaporated, and the residue purified by chromatography using ethyl acetatedichloromethane $(1: 5)$ followed by crystallization from ethanol to give methyl $S$-3-t-butyloxycarbonyl-2-thioxooxazolidine4-carboxylate 16 (8.70 g, 78\%) as fine white crystals, m.p. 101$103{ }^{\circ} \mathrm{C}$. Anal. calcd for $\mathrm{C}_{10} \mathrm{H}_{15} \mathrm{NO}_{5} \mathrm{~S}: \mathrm{C}, 45.97 ; \mathrm{H}: 5.79 ; \mathrm{N}: 5.36 \%$, found $\mathrm{C}, 46.05 ; \mathrm{H}, 5.94 ; \mathrm{N}, 5.42 \% ; \delta_{\mathrm{H}}\left(400 \mathrm{MHz}, \mathrm{DMSO}_{6}\right): 5.09$ $(1 \mathrm{H}, \mathrm{dd}, J=9.6,4.2 \mathrm{~Hz}, 4-H), 4.74\left(1 \mathrm{H}, \mathrm{t}, J=9.6 \mathrm{~Hz}, 5-H_{\alpha}\right), 4.52$ $\left(1 \mathrm{H}, \mathrm{dd}, J=9.6,4.2 \mathrm{~Hz}, 5-H_{\beta}\right), 3.84\left(3 \mathrm{H}, \mathrm{s}, \mathrm{OCH}_{3}\right), 1.52(9 \mathrm{H}, \mathrm{s}$, $\left.\mathrm{C}\left(\mathrm{CH}_{3}\right)_{3}\right) ; \delta_{\mathrm{C}}\left(100 \mathrm{MHz}, \mathrm{DMSO}-\mathrm{d}_{6}\right): 183.5(\mathrm{C}=\mathrm{S}), 168.8\left(\mathrm{CO}_{2} \mathrm{Me}\right)$, $148.4(\mathrm{~N}-C=\mathrm{O}), 85.4\left(C \mathrm{Me}_{3}\right), 68.8(5-C), 59.9(4-C), 53.3\left(\mathrm{OCH}_{3}\right)$, $27.7\left(\mathrm{C}\left(\mathrm{CH}_{3}\right)_{3}\right)$; $\nu_{\text {max }}: 1752,1314,1258,1222,1142,1063,1024$, 967, 843, 773, 591; m/z: (ESI) $284\left([\mathrm{M}+\mathrm{Na}]^{+}\right), 162 ;$ HRMS: (ESI) for $[\mathrm{M}+\mathrm{H}]^{+} \mathrm{C}_{10} \mathrm{H}_{16} \mathrm{NO}_{5} \mathrm{~S}$ requires 262.0744, found 262.0736.

\section{Preparation of 17}

To a solution of the thione $\mathbf{1 4}(217 \mathrm{mg}, 1.0 \mathrm{mmol})$ in chloroform $(10 \mathrm{ml})$ was added mercuric (II) acetate $(435 \mathrm{mg}, 1.4 \mathrm{mmol})$. The reaction mixture was stirred for $2 \mathrm{~h}$ before being filtered and the solid residue washed with chloroform. The filtrate was collected, mixed with water $(10 \mathrm{ml})$, and the solution was neutralised with solid sodium bicarbonate. The organic layer was separated, dried over magnesium sulphate and concentrated by evaporation to give 3-t-butyloxycarbonyl-4-methyl-oxazolidine-2one 17 (187 mg, 93\%) as a white solid, m.p. 94-95 ${ }^{\circ} \mathrm{C}$. Anal. calcd for $\mathrm{C}_{9} \mathrm{H}_{15} \mathrm{NO}_{4}$ : C, 49.75; H, 6.96; N: 6.40\%; found: C, 49.87; $\mathrm{H}$, 7.01; N: 6.39\%; $\delta_{\mathrm{H}}\left(400 \mathrm{MHz}, \mathrm{CDCl}_{3}\right): 4.28-4.36\left(2 \mathrm{H}, \mathrm{m}, 4-, 5-H_{\alpha}\right)$, $3.86\left(1 \mathrm{H}, \mathrm{dd}, J=2.8,7.8 \mathrm{~Hz}, 5-H_{\beta}\right), 1.48\left(9 \mathrm{H}, \mathrm{s}, 3 \times \mathrm{CH}_{3}\right), 1.36$ $\left(3 \mathrm{H}, \mathrm{d}, J=6.2 \mathrm{~Hz}, 4-\mathrm{CH}_{3}\right) ; \delta_{\mathrm{C}}\left(100 \mathrm{MHz}, \mathrm{CDCl}_{3}\right): 152.2(2-\mathrm{C})$, $149.3(\mathrm{~N}-\mathrm{C}=\mathrm{O}), 83.8\left(C\left(\mathrm{CH}_{3}\right)_{3}\right), 68.3(5-C), 51.2(4-C), 28.0(3 \times$ $\mathrm{CH}_{3}$ ), 19.7 (4-CH$)$; v max: 2989, 1773, 1719, 1354, 1217, 1151, 1108, 1086, 1049, 984, 846, 773, 758, $749 \mathrm{~cm}^{-1}$; HRMS: (ESI) for $[\mathrm{M}+\mathrm{H}]^{+} \mathrm{C}_{9} \mathrm{H}_{16} \mathrm{NO}_{4}$ requires 202.1074, found 202.1074.

\section{Reactions of 14}

(a) With sodium pyridine-2-thiolate. A solution of the sodium salt of 2-mercaptopyridine in dry THF $(15 \mathrm{ml})$, formed from 2-mercaptopyridine (101.4 $\mathrm{mg}, 0.108 \mathrm{ml}, 0.92 \mathrm{mmol}$ ) and sodium hydride (60\% dispersion in oil, $74 \mathrm{mg}, 1.84 \mathrm{mmol}$ ), was added to a solution of $14(200 \mathrm{mg}, 0.92 \mathrm{mmol})$ in dry THF (10 $\mathrm{ml}$ ). The mixture was stirred and heated to reflux overnight. The pale red solution was left to cool to room temperature, several drops of water were added, and the mixture stirred for $30 \mathrm{~min}$. The solvent was evaporated, and the residue was extracted with dichloromethane $(2 \times 20 \mathrm{ml})$ and the extract washed with water $(30 \mathrm{ml})$ and dried with sodium sulfate. The crude product was purified by chromatography using cyclohexane-ethyl acetate (1:1, increasing to $1: 4)$ to give $19(60.0 \%)$ and $20(6.5 \%)$. $N$-t-Butyloxycarbonyl-1-(pyrid-2'-ylthio)prop-2-ylamine, 19, pale yellow solid (148 mg, 60.0\%); m.p. $56-57{ }^{\circ} \mathrm{C}$. Anal. calcd for $\mathrm{C}_{13} \mathrm{H}_{20} \mathrm{~N}_{2} \mathrm{O}_{2} \mathrm{~S}$ : C, 58.20; H, 7.46; N, 10.44\%; found: C, 58.33; H, $7.41 ; \mathrm{N}, 10.36 \% ; \delta_{\mathrm{H}}\left(400 \mathrm{MHz}, \mathrm{CDCl}_{3}\right): 8.40(1 \mathrm{H}, \mathrm{br}-\mathrm{d}, J=4.0 \mathrm{~Hz}$, $\left.6^{\prime}-H\right), 7.46\left(1 \mathrm{H}, \mathrm{dt}, J=1.8,7.8 \mathrm{~Hz}, 4^{\prime}-H\right), 7.23(1 \mathrm{H}, \mathrm{d}, J=8.0 \mathrm{~Hz}$, $\left.3^{\prime}-H\right)$, 6.97-7.00 (1H, m, 5'-H), $5.49(1 \mathrm{H}, \mathrm{s}, \mathrm{NH}), 3.90-4.05(1 \mathrm{H}, \mathrm{m}$, 2- $H)$, 3.22-3.40 (2H, m, 1- $\left.H_{2}\right), 1.39\left(9 \mathrm{H}, \mathrm{s}, 3 \times \mathrm{CH}_{3}\right), 1.25(3 \mathrm{H}, \mathrm{d}$, $\left.J=6.8,3-H_{3}\right) ; \delta_{\mathrm{C}}\left(100 \mathrm{MHz}, \mathrm{CDCl}_{3}\right): 155.4(\mathrm{~N}-C=\mathrm{O}), 158.7$, 149.1, 135.9, $122.3 \& 119.5\left(\mathrm{Ar}-C_{5}\right), 78.8\left(C-\left(\mathrm{CH}_{3}\right)_{3}\right), 47.1(2-C)$, $36.0(1-C), 28.3\left(3 \times C \mathrm{H}_{3}\right), 20.3(3-C)$; $v_{\text {max }}: 3359,2973,1678$, 1581, 1519, 1415, 1167, 1154, 1125, 1059, 1053, 752, 578, 399 $\mathrm{cm}^{-1} ; \mathrm{m} / \mathrm{z}$ : (ESI) $269\left([\mathrm{M}+\mathrm{H}]^{+}\right), 152 ; H R M S$ : (ESI) for $[\mathrm{M}+\mathrm{H}]^{+}$ $\mathrm{C}_{13} \mathrm{H}_{21} \mathrm{~N}_{2} \mathrm{O}_{2}$ requires 269.1318, found: 269.1324. $\mathrm{N}, \mathrm{N}-\mathrm{Di}(\mathrm{t}$ butoxycarbonyl)-1-(pyrid-2'-ylthio)propyl-2-amine 20, pale thick oil, (22 mg, 6.5\%). $\delta_{\mathrm{H}}\left(400 \mathrm{MHz}, \mathrm{CDCl}_{3}\right): 8.38(1 \mathrm{H}, \mathrm{d}, J=4.0 \mathrm{~Hz}$, $\left.6^{\prime}-H\right), 7.40-7.44\left(1 \mathrm{H}, \mathrm{m}, 4^{\prime}-H\right), 7.11-7.15\left(1 \mathrm{H}, \mathrm{m}, 3^{\prime}-H\right), 6.91-6.95$ $\left(1 \mathrm{H}, \mathrm{m}, 5^{\prime}-H\right), 4.49-4.58(1 \mathrm{H}, \mathrm{m}, 2-H), 3.47-3.56\left(2 \mathrm{H}, \mathrm{m}, 1-H_{2}\right)$, $1.43\left(18 \mathrm{H}, \mathrm{s}, 6 \times \mathrm{CH}_{3}\right), 1.39\left(3 \mathrm{H}, \mathrm{d}, J=7.2 \mathrm{~Hz}, 3-H_{3}\right) ; \delta_{\mathrm{C}}(100$ $\left.\mathrm{MHz}, \mathrm{CDCl}_{3}\right): 157.1(2 \times \mathrm{N}-\mathrm{C}=\mathrm{O}), 159.1,149.1,135.7,122.3 \&$ $119.5\left(\mathrm{Ar}-C_{5}\right), 82.0\left(2 \times C\left(\mathrm{CH}_{3}\right)_{3}\right), 52.2(2-C), 34.6(1-C), 27.9(6 \times$ $\mathrm{CH}_{3}$ ), 17.9 (3-C); $v_{\max }: 3049,2978,1942,1699,1577,1553,1454$, 1337, 1212, 1142, 1121, 1039, 985, $752 \& 395 \mathrm{~cm}^{-1}$; $m / z$ : (ESI) 369 $\left([\mathrm{M}+\mathrm{H}]^{+}\right), 269,213,152 ; H R M S$ : (ESI) for $[\mathrm{M}+\mathrm{H}]^{+}, \mathrm{C}_{18} \mathrm{H}_{29} \mathrm{~N}_{2} \mathrm{O}_{4} \mathrm{~S}$ requires 369.1843 ; found: 369.1838 .

(b) With sodium phenylthiolate. To a solution of the sodium salt of thiophenol in dry THF $(15 \mathrm{ml})$, formed from thiophenol (101.4 mg, $0.108 \mathrm{ml}, 0.92 \mathrm{mmol}$ ) and sodium hydride (60\% dispersion in oil, $74 \mathrm{mg}, 1.84 \mathrm{mmol}$ ), was added to a solution of 14 (200 mg, $0.92 \mathrm{mmol})$ in dry THF $(10 \mathrm{ml})$. The mixture was stirred and heated to $60{ }^{\circ} \mathrm{C}$ for $4 \mathrm{~h}$. After adding some drops of water, the mixture was left stirring for $30 \mathrm{~min}$. The clear solution was diluted with water $(30 \mathrm{ml})$ and extracted with dichloromethane $(2 \times 20 \mathrm{ml})$. The organic layer was evaporated, and the crude product was purified by chromatography eluting with cyclohexane-ethyl acetate $(10: 1)$. The separation gave three compounds 22 (32.0\%), 23 (4.5\%) and 24 (38.3\%). N-1-t-Butoxycarbonyl-1-phenylthiopropyl-2-amine 22 is a white solid (78 mg, 32.0\%), m.p. $62-63{ }^{\circ} \mathrm{C}$. Anal. calcd for $\mathrm{C}_{14} \mathrm{H}_{21} \mathrm{NO}_{2} \mathrm{~S}: \mathrm{C}, 62.92 ; \mathrm{H}, 7.86 ; \mathrm{N}, 5.24 \%$; found: C, 63.00; $\mathrm{H}$, 7.96; N, 5.21\%; $\delta_{\mathrm{H}}\left(400 \mathrm{MHz}, \mathrm{CD}_{3} \mathrm{OD}\right): 7.37(2 \mathrm{H}, \mathrm{d}, J=8.0 \mathrm{~Hz}$, ortho Ar- $\left.H_{2}\right), 7.27\left(2 \mathrm{H}, \mathrm{t}, J=8.0 \mathrm{~Hz}\right.$, meta $\left.\mathrm{Ar}-\mathrm{H}_{2}\right), 7.15(1 \mathrm{H}, \mathrm{t}, J=$ $7.2 \mathrm{~Hz}$, para Ar- $H)$, 3.68-3.77 $(1 \mathrm{H}, \mathrm{m}, 2-H), 3.09(1 \mathrm{H}, \mathrm{br}-\mathrm{dd}, J=$ $\left.6.0,13.0 \mathrm{~Hz}, 1-H_{\alpha}\right), 2.88\left(1 \mathrm{H}, \mathrm{dd}, J=7.2,13.0 \mathrm{~Hz}, 1-H_{\beta}\right), 1.41(9 \mathrm{H}$, $\left.\mathrm{s}, 3 \times \mathrm{CH}_{3}\right), 1.18\left(3 \mathrm{H}, \mathrm{d}, J=6.8 \mathrm{~Hz}, 3-H_{3}\right) ; \delta_{\mathrm{C}}\left(100 \mathrm{MHz}, \mathrm{CD}_{3} \mathrm{OD}\right):$ $157.6(\mathrm{~N}-C=\mathrm{O}), 137.8,130.3,129.9 \& 127.0,\left(\mathrm{Ar}-C_{6}\right), 79.9(C-$ $\left.\left(\mathrm{CH}_{3}\right)_{3}\right), 48.6(2-\mathrm{C}), 40.8(1-\mathrm{C}), 28.8\left(3 \times \mathrm{CH}_{3}\right), 20.0(3-\mathrm{C})$; $v_{\text {max }}$ : 3368, 2976, 1681, 1518, 1244, 1153, 1026, 737, 610, $468 \mathrm{~cm}^{-1}$; $m / z:(\mathrm{EI}) 290\left([\mathrm{M}+\mathrm{Na}]^{+}\right), 212,151 ; H R M S:(\mathrm{EI})$ for $[\mathrm{M}+\mathrm{Na}]^{+}$ $\mathrm{C}_{14} \mathrm{H}_{21} \mathrm{NO}_{2} \mathrm{SNa}$ requires 290.1185; found: 290.1189 .

N,N-Bis(t-butoxycarbonyl)-1-(phenylthio)propyl-2-amine 23, clear colourless liquid (15 mg, 4.45\%). Anal. calcd for $\mathrm{C}_{19} \mathrm{H}_{29} \mathrm{NO}_{4} \mathrm{~S}: \mathrm{C}, 62.12 ; \mathrm{H}, 7.90 ; \mathrm{N}, 3.81 \%$; found: C, 62.14; $\mathrm{H}$, 7.83; N, 3.96\%; $\delta_{\mathrm{H}}\left(400 \mathrm{MHz}, \mathrm{CDCl}_{3}\right): 7.29(2 \mathrm{H}, \mathrm{d}, J=7.8 \mathrm{~Hz}$, 
ortho $\left.\mathrm{Ar}-\mathrm{H}_{2}\right), 7.19\left(2 \mathrm{H}, \mathrm{t}, J=7.8 \mathrm{~Hz}\right.$, meta Ar- $\left.H_{2}\right), 7.10(1 \mathrm{H}, \mathrm{t}, J=$ $7.2 \mathrm{~Hz}$, para Ar- $H$ ), 4.28-4.37 (1H, m, 2-H), 3.35 (1H, dd, $J=8.0$, 13.6, $\left.1-H_{\alpha}\right), 3.06\left(1 \mathrm{H}, \mathrm{dd}, J=7.2,13.6 \mathrm{~Hz}, 1-H_{\beta}\right), 1.39(18 \mathrm{H}, \mathrm{s}, 6 \times$ $\left.\mathrm{CH}_{3}\right), 1.30\left(3 \mathrm{H}, \mathrm{d}, J=6.8 \mathrm{~Hz}, 3-H_{3}\right) ; \delta_{\mathrm{C}}\left(100 \mathrm{MHz}, \mathrm{CDCl}_{3}\right): 152.8$ $(2 \times \mathrm{N}-C=\mathrm{O}), 135.8,129.5,128.8 \& 126.1,\left(\operatorname{Ar}-C_{6}\right), 82.2(2 \times$ $\left.C\left(\mathrm{CH}_{3}\right)_{3}\right), 52.2(2-\mathrm{C}), 38.6(1-\mathrm{C}), 27.9\left(6 \times \mathrm{CH}_{3}\right), 17.6\left(\mathrm{CH}_{3}\right) ; v_{\max }$ : 2978, 1736, 1699, 1367, 1345, 1273, 1142, 740, $691 \mathrm{~cm}^{-1} ; \mathrm{m} / \mathrm{z}$ : (ESI) $390\left([\mathrm{M}+\mathrm{Na}]^{+}\right), 268,151 ; H R M S$ : (ESI) for $[\mathrm{M}+\mathrm{H}]^{+}$ $\mathrm{C}_{19} \mathrm{H}_{30} \mathrm{NO}_{4} \mathrm{~S}$ requires 368.1890, found: 368.1890. rac- $R, R, R$ - and rac- $R, R, S-1,3,5$-tris(1'-(phenylthio)prop-2'-yl)hexahydro-1,3,5-triazine2,4,6-trione 24, clear colourless liquid (68 mg, 12.8\%). $\delta_{\mathrm{H}}(400$ $\left.\mathrm{MHz}, \mathrm{CDCl}_{3}\right): 7.35\left(6 \mathrm{H}, \mathrm{d}, J=7.8 \mathrm{~Hz}, 3 \times\right.$ ortho $\left.\mathrm{Ar}-\mathrm{H}_{2}\right), 7.33(6 \mathrm{H}, \mathrm{t}$, $J=7.8 \mathrm{~Hz}, 3 \times$ meta Ar- $\left.H_{2}\right), 7.25\left(3 \mathrm{H}, \mathrm{t}, J=7.2 \mathrm{~Hz}, 3 \times\right.$ para $\left.\mathrm{Ar}-H_{1}\right)$, 4.88-4.98 (3H, m, $\left.3 \times 2^{\prime}-H\right), 3.53-3.62\left(3 \mathrm{H}, \mathrm{m}, 3 \times 1^{\prime}-H_{\alpha}\right), 3.15-3.23$ $\left(3 \mathrm{H}, \mathrm{m}, 3 \times 1^{\prime}-H_{\beta}\right), 1.44\left(9 \mathrm{H}, \mathrm{d}, J=6.8 \mathrm{~Hz}, 3 \times 3^{\prime}-H_{3}\right) ; \delta_{\mathrm{C}}(100 \mathrm{MHz}$, $\left.\mathrm{CDCl}_{3}\right): 159.4\left(3 \times \mathrm{N}_{2}-C=\mathrm{O}\right), 135.3,130.4,130.2, \& 126.8(3 \times \mathrm{Ar}-$ $\left.C_{6}\right), 51.1\left(3 \times 2^{\prime}-C\right), 37.1\left(3 \times 1^{\prime}-C\right), 17.3\left(3 \times 3^{\prime}-C\right)$; $v_{\max }: 2975$, 1683, 1425, 1369, 1024, 762, 734, 689, $421 \mathrm{~cm}^{-1}$; m/z: (EI) 579 $\left([\mathrm{M}]^{+}\right), 151,150 ;$ HRMS: (ESI) for $[\mathrm{M}+\mathrm{H}]^{+}, \mathrm{C}_{30} \mathrm{H}_{34} \mathrm{~N}_{3} \mathrm{O}_{3} \mathrm{~S}_{3}$ requires 580.1749 , found 580.1749 . The multiplicities of resonances in region $\delta_{\mathrm{H}} 3-4 \mathrm{ppm}$ indicate that two diastereomers are present.

(c) With sodium ethanethiolate. $14(200 \mathrm{mg}, 0.92 \mathrm{mmol})$ and sodium ethanethiolate (339 $\mathrm{mg}, 0.92 \mathrm{mmol}$ ) were dissolved in dry xylene $(10 \mathrm{ml})$ and the mixture was stirred and irradiated in a microwave oven at $145{ }^{\circ} \mathrm{C}$ for $1 \mathrm{~h}$. After cooling to room temperature the reaction mixture was dissolved in dichloromethane $(15 \mathrm{ml})$ and was washed with distilled water $(2 \times$ $10 \mathrm{ml}$ ). The organic layer was dried over sodium sulfate, and solvent removed in vacuo. The crude residue was purified by chromatography using cyclohexane-ethyl acetate $(2: 1)$ as eluent to give $\mathrm{N}$-t-butoxycarbonyl-1-(ethylthio)propyl-2-amine 26 as a pale yellow oil $(116 \mathrm{mg}, 57.6 \%)$. Anal. calcd for $\mathrm{C}_{10} \mathrm{H}_{21} \mathrm{NO}_{2} \mathrm{~S}$ : C, 54.76; H, 9.65; N, 6.39\%; found: C, 54.82; H, 9.49; N, 6.27\%; $\delta_{\mathrm{H}}\left(400 \mathrm{MHz}, \mathrm{CDCl}_{3}\right): 4.59(1 \mathrm{H}, \mathrm{s}, \mathrm{NH}), 3.71-3.80(1 \mathrm{H}, \mathrm{br}-\mathrm{m}, 2-$ $H), 2.63\left(1 \mathrm{H}, \mathrm{dd}, J=5.0,13.3 \mathrm{~Hz}, 1-H_{\alpha}\right), 2.47-2.53\left(3 \mathrm{H}, \mathrm{m}, 1-H_{\beta}\right.$, $\left.-\mathrm{CH}_{2} \mathrm{Me}\right), 1.37\left(9 \mathrm{H}, \mathrm{s}, 3 \times \mathrm{CH}_{3}\right), 1.20\left(3 \mathrm{H}, \mathrm{t}, J=7.3 \mathrm{~Hz}, \mathrm{CH}_{2} \mathrm{CH}_{3}\right)$, $1.14\left(3 \mathrm{H}, \mathrm{d}, J=6.8 \mathrm{~Hz}, 3-H_{3}\right) ; \delta_{\mathrm{C}}\left(100 \mathrm{MHz}, \mathrm{CDCl}_{3}\right): 155.1(\mathrm{~N}-\mathrm{C}=$ O), $79.2\left(C-\left(\mathrm{CH}_{3}\right)_{3}\right), 45.9(2-\mathrm{C}), 38.4(1-\mathrm{C}), 28.3\left(3 \times \mathrm{CH}_{3}\right), 26.7$ $\left(\mathrm{S}-\mathrm{CH}_{2} \mathrm{Me}\right), 19.8(3-\mathrm{C}), 14.8\left(\mathrm{CH}_{2} \mathrm{CH}_{3}\right) ; v_{\max }: 3332,2972,2928$, 1689, 1506, 1365, 1246, 1166, 1048, $1025 \mathrm{~cm}^{-1}$; m/z: (ESI) 220 $[\mathrm{M}+\mathrm{H}]^{+}, 164,146 ; H R M S$ : (ESI) for $[\mathrm{M}+\mathrm{H}]^{+} \mathrm{C}_{10} \mathrm{H}_{22} \mathrm{NO}_{2} \mathrm{~S}$ requires 220.1366 , found: 220.1368 .

(d) With potassium thioacetate. Potassium thioacetate (116 mg, $1.01 \mathrm{mmol}$ ) was added to a solution of 14 (200 mg, 0.92 $\mathrm{mmol})$ dissolved in dry DMF $(20 \mathrm{ml})$ under anhydrous conditions. The mixture was stirred at $20{ }^{\circ} \mathrm{C}$ for $12 \mathrm{~h}$. After adding some drops of water, and stirring for $30 \mathrm{~min}$, the mixture was concentrated in vacuo. The crude material was purified by chromatography (cyclohexane-ethyl acetate $4: 1$ ) to give $N$ acetyl-S-t-butoxycarbonyl-1-mercaptopropyl-2-amine 28 as a yellow liquid (70 mg, 32.6\%). Anal. calcd for $\mathrm{C}_{10} \mathrm{H}_{19} \mathrm{NO}_{3} \mathrm{~S}: \mathrm{C}$, 51.48; H, 8.21; N, 6.00\%; found: C, 51.33; H, 7.92; N, 5.92\%; $\delta_{\mathrm{H}}$ $\left(400 \mathrm{MHz}_{\mathrm{CDCl}}\right): 5.76(1 \mathrm{H}, \mathrm{s}, \mathrm{NH}), 4.06-4.16(1 \mathrm{H}, \mathrm{m}, 2-H)$, 2.87-2.90 (2H, m, 1- $\left.\mathrm{H}_{2}\right), 1.86\left(3 \mathrm{H}, \mathrm{s}, \mathrm{COCH}_{3}\right), 1.43(9 \mathrm{H}, \mathrm{s}, 3 \times$ $\left.\mathrm{CH}_{3}\right), 1.14\left(3 \mathrm{H}, \mathrm{d}, J=6.4 \mathrm{~Hz}, 3-H_{3}\right) ; \delta_{\mathrm{C}}\left(100 \mathrm{MHz}, \mathrm{CDCl}_{3}\right): 169.5$ $(\mathrm{S}-C=\mathrm{O}), 159.8(\mathrm{~N}-C=\mathrm{O}), 85.3\left(C-\left(\mathrm{CH}_{3}\right)_{3}\right), 46.0(2-C), 36.3(1-C)$, $28.1\left(3 \times \mathrm{CH}_{3}\right), 23.3\left((\mathrm{O}=\mathrm{C}) \mathrm{CH}_{3}\right), 19.9$ (3-C); v $\max : 3278,2979$, 1702, 1645, 1547, 1369, 1200, 1123, 838, $732 \mathrm{~cm}^{-1}$; m/z: (ESI) 234 $\left([\mathrm{M}+\mathrm{H}]^{+}\right), 178,156 ; H R M S$ : (ESI) for $[\mathrm{M}+\mathrm{H}]^{+} \mathrm{C}_{10} \mathrm{H}_{20} \mathrm{NO}_{3} \mathrm{~S}$ requires 234.1158, found: 234.1159 .

(e) With tetrabutylammonium iodide. Tetrabutylammonium iodide (339 mg, $0.92 \mathrm{mmol}$ ) and 14 (200 mg, $0.92 \mathrm{mmol}$ ) were dissolved in dry xylene $(10 \mathrm{ml})$ and the mixture was stirred and irradiated in a microwave oven at $145{ }^{\circ} \mathrm{C}$ for $1 \mathrm{~h}$. After cooling to room temperature the reaction mixture was dissolved in dichloromethane $(15 \mathrm{ml})$ and was washed with distilled water $(2 \times 10 \mathrm{ml})$. The organic layer was dried over sodium sulfate, and solvent removed in vacuo. The crude residue was purified by chromatography using cyclohexane-ethyl acetate $(2: 1)$ as eluent to give $N$-t-butoxycarbonyl-4-methyl-1,3-thiazolidin-2-one 31 as a white solid (114 mg, 57.0\%), which was crystallized from ethyl acetate, m.p. $77-78{ }^{\circ} \mathrm{C}$. Anal. calcd for $\mathrm{C}_{9} \mathrm{H}_{15} \mathrm{NO}_{3} \mathrm{~S}$ : C, 49.75; H, 6.96; N, 6.45\%, found: C, 49.87; H, 7.03; N, 6.39\%; $\delta_{\mathrm{H}}$ (400 $\left.\mathrm{MHz}, \mathrm{CDCl}_{3}\right): 4.50-4.57(1 \mathrm{H}$, quin., $J=6.8 \mathrm{~Hz}, 4-H), 3.51$ $\left(1 \mathrm{H}, \mathrm{dd}, J=11.0,7.8 \mathrm{~Hz}, 5-H_{\alpha}\right), 2.72\left(1 \mathrm{H}, \mathrm{d}, J=11.0 \mathrm{~Hz}, 5-H_{\beta}\right)$, $1.45\left(9 \mathrm{H}, \mathrm{s}, 3 \times \mathrm{CH}_{3}\right), 1.35\left(3 \mathrm{H}, \mathrm{d}, J=6.2 \mathrm{~Hz}, 4-\mathrm{CH}_{3}\right) ; \delta_{\mathrm{C}}(100$ $\left.\mathrm{MHz}, \mathrm{CDCl}_{3}\right): 169.6(2-C), 148.5(\mathrm{~N}-\mathrm{C}=\mathrm{O}), 83.3\left(C\left(\mathrm{CH}_{3}\right)_{3}\right), 54.6$ (4-C), $31.6(5-C), 27.7\left(3 \times \mathrm{CH}_{3}\right), 18.7\left(4-\mathrm{CH}_{3}\right)$; $v_{\text {max }}: 2977,1755$, 1672, 1369, 1354, 1326, 1278, 1245, 1169, 1147, 942, 859, 768, 672, $548 \mathrm{~cm}^{-1} ; \mathrm{m} / z:(\mathrm{ESI}) 235\left(\left[\mathrm{M}+\mathrm{NH}_{4}\right]^{+}\right), 218\left([\mathrm{M}+\mathrm{H}]^{+}\right), 162$, 144; HRMS: (ESI) for $\left[\mathrm{M}+\mathrm{NH}_{4}\right]^{+} \mathrm{C}_{9} \mathrm{H}_{19} \mathrm{~N}_{2} \mathrm{O}_{3} \mathrm{~S}$ requires 235.1111, found: 235.1114 .

(f) With $n$-butyl lithium. $n$-Butyl lithium $(0.37 \mathrm{ml}, 2.5 \mathrm{M}$, $0.92 \mathrm{mmol}$ ) was added to a stirred solution of 14 (200 $\mathrm{mg}, 0.92$ $\mathrm{mmol})$ in anhydrous tetrahydrofuran $(20 \mathrm{ml})$, under a nitrogen atmosphere at $-78{ }^{\circ} \mathrm{C}$. The solution was allowed to warm to $20{ }^{\circ} \mathrm{C}$ and was stirred overnight and became yellow. After adding some drops of a mixture of THF and water, and stirring for $30 \mathrm{~min}$, the solvent was evaporated. The residue was extracted with dichloromethane $(2 \times 20 \mathrm{ml})$ and the extract was washed with water $(30 \mathrm{ml})$. The organic layer was evaporated and the resulting residue was chromatographed using cyclohexaneethyl acetate $(2: 1)$ to give the product $O-\left(2^{\prime}-((\right.$ tert-butoxycarbonyl)amino)propyl) thiopentanoate $34(116 \mathrm{mg}, 45.9 \%)$ as a yellow liquid. Anal. calcd for $\mathrm{C}_{13} \mathrm{H}_{25} \mathrm{NO}_{3} \mathrm{~S}: \mathrm{C}, 56.72 ; \mathrm{H}, 9.09 ; \mathrm{N}$, $5.09 \%$; found: $\mathrm{C}, 56.68 ; \mathrm{H}, 9.15 ; \mathrm{N}, 5.05 \% ; \delta_{\mathrm{H}}(400 \mathrm{MHz}$, $\left.\mathrm{CD}_{3} \mathrm{OD}\right): 4.36\left(1 \mathrm{H}, \mathrm{dd}, J=10.8,4.9 \mathrm{~Hz}, 1^{\prime}-H_{\alpha}\right), 4.24-4.30(1 \mathrm{H}, \mathrm{br}-$ $\left.\mathrm{dd}, J=10.8,7.8 \mathrm{~Hz}, 1^{\prime}-H_{\beta}\right), 3.96-4.04\left(1 \mathrm{H}, \mathrm{m}, 2^{\prime}-H\right), 2.72(2 \mathrm{H}, \mathrm{t}$, $\left.J=8.0 \mathrm{~Hz}, 2-H_{2}\right), 1.67-1.75\left(2 \mathrm{H}, \mathrm{m}, 3-H_{2}\right), 1.41\left(9 \mathrm{H}, \mathrm{s}, 3 \times \mathrm{CH}_{3}\right)$, 1.32-1.41 (2H, m, 4- $\left.H_{2}\right), 1.16\left(3 \mathrm{H}, \mathrm{d}, J=6.8 \mathrm{~Hz}, 3^{\prime}-H_{3}\right), 0.90(3 \mathrm{H}$, $\left.\mathrm{t}, J=6.8 \mathrm{~Hz}, 5-H_{3}\right) ; \delta_{\mathrm{C}}\left(100 \mathrm{MHz} \mathrm{CD}_{3} \mathrm{OD}\right): 224.2(C=\mathrm{S}), 157.3(\mathrm{~N}-$ $C=\mathrm{O}), 78.7\left(C\left(\mathrm{CH}_{3}\right)_{3}\right), 74.3\left(1^{\prime}-C\right), 46.8\left(2^{\prime}-C\right), 45.4(2-C), 31.7$ (3$C), 27.5\left(3 \times \mathrm{CH}_{3}\right), 21.6(4-C), 16.3\left(3^{\prime}-C\right), 12.9$ (5-C); $v_{\max }: 3333$, 2963, 2934, 1688, 1505, 1490, 1442, 1387, 1366, 1351, 1246, 1188, 1164, 1101, 1068, 1032, 930, 921, $804 \mathrm{~cm}^{-1}$; m/z: (EI) 276 $\left([\mathrm{M}+\mathrm{H}]^{+}\right), 260,220,204,186,180,160 ; H R M S:(\mathrm{EI})$ for $[\mathrm{M}+\mathrm{H}]^{+}$ $\mathrm{C}_{13} \mathrm{H}_{26} \mathrm{NO}_{3} \mathrm{~S}$ requires 276.1629, found: 276.1631.

(g) With sec-butyl lithium. Prepared following procedure for 34 above, but using sec-butyl lithium $(0.79 \mathrm{ml}, 1.4 \mathrm{M}$, $1.1 \mathrm{mmol}$ ) instead of $n$-butyl lithium. The product was isolated by chromatography using cyclohexane-ethyl acetate $(19: 1)$ to give $\mathrm{O}$-(N-t-butoxycarbonyl)-2'-aminopropyl 2-methylthiobutanonate 35 (134 mg, 53\%) as a white solid, m.p. 58-59 ${ }^{\circ} \mathrm{C}$, two 
diastereomers (ca. $1: 1), \delta_{\mathrm{H}}\left(400 \mathrm{MHz}, \mathrm{CDCl}_{3}\right): 4.47(1 \mathrm{H}, \mathrm{br}, \mathrm{NH})$, 4.24-4.37 (2H, m, 1'- $\mathrm{H}_{2}$ ), 4.03-4.21 (1H, br, $\left.2^{\prime}-H\right)$, 2.76 (1H, hex., $J=6.9 \mathrm{~Hz}, 2-H), 1.37\left(9 \mathrm{H}, \mathrm{s}, 3 \times \mathrm{CH}_{3}\right), 1.62-1.75\left(1 \mathrm{H}, \mathrm{m}, 3-H_{\alpha}\right)$, 1.52-1.41 (1H, m, 3- $\left.H_{\beta}\right), 1.16\left(6 \mathrm{H}, 2 \times \mathrm{d}, J=7.3 \mathrm{~Hz}, 3^{\prime}-H_{3}, 2-\right.$ $\left.\mathrm{CH}_{3}\right), 0.82\left(3 \mathrm{H}, \mathrm{t}, J=7.4 \mathrm{~Hz}, 4-H_{3}\right) ; \delta_{\mathrm{C}}\left(100 \mathrm{MHz}, \mathrm{CDCl}_{3}\right): 229.12$ and $229.09(C=\mathrm{S}), 155.0(\mathrm{~N}-C=\mathrm{O}), 79.5\left(\mathrm{O}-C\left(\mathrm{CH}_{3}\right)_{3}\right), 74.44$ and $74.38\left(1^{\prime}-C\right), 52.25$ and $52.21(2-C), 45.4$ and $45.3\left(2^{\prime}-C\right), 29.6$ and 29.5 (3-C), 28.3 (O-C- $\left.\left(\mathrm{CH}_{3}\right)_{3}\right), 19.92$ and $19.90\left(2-\mathrm{CH}_{3}\right), 18.0\left(3^{\prime}-\right.$ C), 11.7 (4-C); $v_{\text {max }}: 3345,2975,2936,1682,1528,1455,1368$, 1345, 1291, 1271, 1267, 1235, 1192, 1154, 1101, 1052, 1007, 982, 851, 753, $636 \mathrm{~cm}^{-1}$; HRMS: (ESI) for $[\mathrm{M}+\mathrm{H}]^{+} \mathrm{C}_{13} \mathrm{H}_{26} \mathrm{NO}_{3} \mathrm{~S}$ requires 276.1628 , found 276.1631 .

(h) With $t$-butyl lithium. Prepared following procedure for 34 above, but using tert-butyl lithium (0.69 ml, 1.6 M, 1.1 mmol) instead of $n$-butyl lithium. The product was isolated by chromatography using cyclohexane-ethyl acetate $(4: 1)$ to give $\mathrm{O}-(\mathrm{N}$ t-butoxycarbonyl)-2'-aminopropyl 2,2-dimethylthiopropionate 36 (240 mg, 94.8\%) as a yellow solid, m.p. $67-68^{\circ} \mathrm{C}$. Anal. calcd for $\mathrm{C}_{13} \mathrm{H}_{25} \mathrm{NO}_{3} \mathrm{~S}: \mathrm{C}, 56.69 ; \mathrm{H}, 9.15 ; \mathrm{N}, 5.09 \%$; found: C, 57.00; H, 9.21; N, 4.96\%. $\delta_{\mathrm{H}}\left(400 \mathrm{MHz}, \mathrm{CDCl}_{3}\right): 4.47(1 \mathrm{H}, \mathrm{br}, \mathrm{NH}), 4.24-$ $4.31\left(2 \mathrm{H}, \mathrm{m}, 1^{\prime}-H_{2}\right), 4.03-4.12\left(1 \mathrm{H}, \mathrm{br}, 2^{\prime}-H\right), 1.37(9 \mathrm{H}, \mathrm{s}, 3 \times$ $\left.\mathrm{CH}_{3}\right), 1.23\left(9 \mathrm{H}, \mathrm{s}, 3 \times \mathrm{CH}_{3}\right), 1.14\left(3 \mathrm{H}, \mathrm{d}, J=6.8 \mathrm{~Hz}, 3^{\prime}-H\right) ; \delta_{\mathrm{C}}(100$ $\left.\mathrm{MHz}, \mathrm{CDCl}_{3}\right): 231.1(C=\mathrm{S}), 155.0(\mathrm{~N}-C=\mathrm{O}), 81.5\left(\mathrm{O}-C\left(\mathrm{CH}_{3}\right)_{3}\right)$, $74.8\left(1^{\prime}-C\right), 67.0(1-C), 47.3\left(2^{\prime}-C\right), 29.7\left(\mathrm{O}-\mathrm{C}-\left(\mathrm{CH}_{3}\right)_{3}\right), 28.3$ (C$\left.\left(\mathrm{CH}_{3}\right)_{3}\right), 17.9\left(3^{\prime}-\mathrm{C}\right), v_{\max }: 3314,2975,1681,1539,1368,1255$, 1211, 1163, 1114, 1059, $658 \mathrm{~cm}^{-1}$; $\mathrm{m} / z$ : (ESI) $276\left([\mathrm{M}+\mathrm{H}]^{+}\right), 260$; HRMS: (ESI) for $[\mathrm{M}+\mathrm{H}]^{+} \mathrm{C}_{13} \mathrm{H}_{26} \mathrm{NO}_{3} \mathrm{~S}$ requires 276.1628 , found 276.1629 .

(i) With lithium dimethylamide. Prepared following procedure for $\mathbf{3 4}$ above but using lithium dimethylamide (1.0 $\mathrm{ml}, 5 \mathrm{wt} \%$ in hexane, $0.92 \mathrm{mmol}$ ). The product was isolated by flash column chromatography using cyclohexane-ethyl acetate (4:1) The separation gave two compounds 37 and 38. $N-t$ Butoxycarbonyl-O-(dimethylaminothiocarbonyl)-2-aminopropanol 37 (75 mg, 31.1\%), a yellow solid, m.p. $87{ }^{\circ} \mathrm{C} . \delta_{\mathrm{H}}(400 \mathrm{MHz}$, $\left.\mathrm{CDCl}_{3}\right): 4.55(1 \mathrm{H}, \mathrm{br}-\mathrm{s}, \mathrm{N} H), 4.30-4.41\left(2 \mathrm{H}, \mathrm{m}, 1-\mathrm{H}_{2}\right), 3.99-4.14$ $(1 \mathrm{H}, \mathrm{br}, 2-\mathrm{H}), 3.29\left(3 \mathrm{H}, \mathrm{s}, \mathrm{N}-\mathrm{CH}_{3}\right), 3.06\left(3 \mathrm{H}, \mathrm{s}, \mathrm{N}-\mathrm{CH}_{3}\right), 1.36(9 \mathrm{H}$, s, $\left.3 \times \mathrm{CH}_{3}\right), 1.13\left(3 \mathrm{H}, \mathrm{d}, J=6.8 \mathrm{~Hz}, 3-H_{3}\right) ; \delta_{\mathrm{C}}\left(100 \mathrm{MHz}, \mathrm{CDCl}_{3}\right)$ : $189.6(C=\mathrm{S}), 155.1(\mathrm{~N}-C=\mathrm{O}), 79.2\left(C\left(\mathrm{CH}_{3}\right)_{3}\right), 76.7(1-C), 46.0$ (2$C), 42.7\left(\mathrm{~N}-\mathrm{CH}_{3}\right), 37.7\left(\mathrm{~N}-\mathrm{CH}_{3}\right), 28.3\left(\mathrm{C}\left(\mathrm{CH}_{3}\right)_{3}\right), 17.7(3-C)$; $v_{\max }$ : 3357, 2977, 1684, 1526, 1366, 1271, 1163, 1025, 634, $549 \mathrm{~cm}^{-1}$; $m / z$ : (ESI) $263\left([\mathrm{M}+\mathrm{H}]^{+}\right), 207 ; H R M S$ : (ESI) for $[\mathrm{M}+\mathrm{H}]^{+}$ $\mathrm{C}_{11} \mathrm{H}_{23} \mathrm{~N}_{2} \mathrm{O}_{3} \mathrm{~S}$ requires 263.1424, found 263.1420. $\mathrm{N}, \mathrm{N}-\mathrm{Di}$ (t-butoxycarbonyl)-O-(dimethylaminothiocarbonyl)-2-aminoethanol 38 (103 mg, 30.9\%), a yellow solid, m.p. 100-102 ${ }^{\circ} \mathrm{C}$. Anal. calcd for $\mathrm{C}_{16} \mathrm{H}_{30} \mathrm{~N}_{2} \mathrm{O}_{5} \mathrm{~S}: \mathrm{C}, 53.01 ; \mathrm{H}, 8.34 ; \mathrm{N}, 7.73 \%$; found: $\mathrm{C}, 53.28 ; \mathrm{H}$, 8.47; N, 7.60\%; $\delta_{\mathrm{H}}\left(400 \mathrm{MHz}, \mathrm{CDCl}_{3}\right): 4.48-4.64\left(3 \mathrm{H}, 2-\mathrm{H}, 1-\mathrm{H}_{2}\right)$, $3.27\left(3 \mathrm{H}, \mathrm{s}, \mathrm{N}-\mathrm{CH}_{3}\right), 3.01\left(3 \mathrm{H}, \mathrm{s}, \mathrm{N}-\mathrm{CH}_{3}\right), 1.42\left(18 \mathrm{H}, \mathrm{s}, 6 \times \mathrm{CH}_{3}\right)$, $1.24\left(3 \mathrm{H}, \mathrm{d}, J=6.8 \mathrm{~Hz}, 3-H_{3}\right) ; \delta_{\mathrm{C}}\left(100 \mathrm{MHz}, \mathrm{CDCl}_{3}\right): 187.6(C=\mathrm{S})$, $152.8(2 \times \mathrm{N}-C=\mathrm{O}), 82.2\left(2 \times C\left(\mathrm{CH}_{3}\right)_{3}\right), 72.2(1-C), 51.0(2-C)$, $42.5\left(\mathrm{~N}-\mathrm{CH}_{3}\right), 37.6\left(\mathrm{~N}-\mathrm{CH}_{3}\right), 27.9\left(2 \times \mathrm{C}\left(\mathrm{CH}_{3}\right)_{3}\right), 15.2(3-C) ; v_{\max }$ : 2977, 1734, 1691, 1539, 1396, 1378, 1367, 1353, 1294, 1276, 1234, 1200, 1174, 1158, 1123, 1045, 1021, $766 \mathrm{~cm}^{-1}$; m/z: (ESI) $363\left([\mathrm{M}+\mathrm{H}]^{+}\right), 307,263 ; H R M S$ : (ESI) for $[\mathrm{M}+\mathrm{H}]^{+} \mathrm{C}_{16} \mathrm{H}_{31} \mathrm{~N}_{2} \mathrm{O}_{5} \mathrm{~S}$ requires 363.1948 , found: 363.1940 .

(j) With phenyl lithium. Prepared following procedure for 34 above, but using phenyl lithium $(0.52 \mathrm{ml}, 1.8 \mathrm{M}$ in diethyl ether, $0.92 \mathrm{mmol}$ ). The product was isolated by chromatography using cyclohexane-ethyl acetate $(2: 1)$ to give 4-methyl-2-phenylthiazoline ${ }^{32} 40(155 \mathrm{mg}, 95.0 \%)$ as a yellow oil. $\delta_{\mathrm{H}}(400 \mathrm{MHz}$, $\left.\mathrm{CDCl}_{3}\right)$ : 7.79-7.84 (2H, m, 2'-, $\left.6^{\prime}-H\right), 7.33-7.43\left(3 \mathrm{H}, \mathrm{m}, 3^{\prime}-, 4^{\prime}-, 5^{\prime}-\right.$ $H), 4.72(1 \mathrm{H}$, hex., $J=6.8 \mathrm{~Hz}, 4-\mathrm{CH}), 3.46(1 \mathrm{H}, \mathrm{dd}, J=6.8,8.4 \mathrm{~Hz}$, $\left.5-H_{\alpha}\right) 2.98\left(1 \mathrm{H}, \mathrm{dd}, J=7.2,8.4 \mathrm{~Hz}, 5-H_{\beta}\right), 1.43(3 \mathrm{H}, \mathrm{d}, J=6.2 \mathrm{~Hz}$, $\left.4-\mathrm{CH}_{3}\right) ; \delta_{\mathrm{C}}\left(100 \mathrm{MHz}, \mathrm{CDCl}_{3}\right): 166.1$ (2-C), 133.1, 130.8, 128.2, $128.1\left(\mathrm{Ar}-C_{6}\right), 72.7(4-C), 39.6(5-C), 20.2\left(4-\mathrm{CH}_{3}\right) ; v_{\max }: 2967$, 1446, 1300, 1249, 1107, 948, 765, 690, 612, $396 \mathrm{~cm}^{-1} ; \mathrm{m} / z:(\mathrm{ESI})$ $178\left([\mathrm{M}+\mathrm{H}]^{+}\right), 162,131,77 ;$ HRMS: (ESI) for $[\mathrm{M}+\mathrm{H}]^{+} \mathrm{C}_{10} \mathrm{H}_{12} \mathrm{NS}$ requires 178.0683 , found: 178.0679 .

(k) With phenyl magnesium bromide. Prepared following procedure for $\mathbf{3 4}$ above, but using phenyl magnesium bromide (3.0 $\mathrm{ml}$ in diethyl ether), gave $\mathbf{4 0}$ (38\%).

(1) With phenylethynyl lithium. Prepared following procedure for 34 above but using lithium phenylacetylide $(1.0 \mathrm{ml}, 1 \mathrm{M}$ in THF, $0.92 \mathrm{mmol})$. The product was purified by chromatography cyclohexane-ethyl acetate $(2: 1)$ to yield 4-methyl-2-(phenylethynyl)thiazoline $\mathbf{4 1}$ as a yellow oil $(110 \mathrm{mg}, 59.5 \%) . \delta_{\mathrm{H}}(400$ $\left.\mathrm{MHz}, \mathrm{CDCl}_{3}\right): 7.44\left(2 \mathrm{H}, \mathrm{d}, J=7.8 \mathrm{~Hz}\right.$, ortho Ar- $\left.H_{2}\right), 7.27(2 \mathrm{H}, \mathrm{t}, J=$ $7.8 \mathrm{~Hz}$, meta $\left.\mathrm{Ar}-H_{2}\right), 7.25\left(1 \mathrm{H}, \mathrm{t}, J=7.2 \mathrm{~Hz}\right.$, para Ar- $\left.H_{1}\right), 4.54-4.58$ $(1 \mathrm{H}, \mathrm{m}, 4-H), 3.44\left(1 \mathrm{H}, \mathrm{dd}, J=7.0,8.3 \mathrm{~Hz}, 5-H_{\alpha}\right), 2.96(1 \mathrm{H}, \mathrm{dd}, J=$ 6.8, 8.3 Hz, 5- $\left.H_{\beta}\right), 1.43\left(3 \mathrm{H}, \mathrm{d}, J=6.2 \mathrm{~Hz}, 4-\mathrm{CH}_{3}\right) ; \delta_{\mathrm{C}}(100 \mathrm{MHz}$, $\left.\mathrm{CDCl}_{3}\right): 163.5(2-C), 132.1,129.8,128.3$ and $122.7\left(\mathrm{Ar}-C_{6}\right), 93.0$ (sp-C), 81.9 (sp- $C$ ) 72.5 (4-C), $40.6(5-C), 20.0\left(4-C_{3}\right) ; v_{\max }: 2980$, 2210, 1704, 1369, 1299, 1205, 1149, 756, $689 \mathrm{~cm}^{-1}$; m/z: (EI) 201 $\left([\mathrm{M}]^{+}\right), 186,155,127 ;$ HRMS: (ESI) for $[\mathrm{M}+\mathrm{H}]^{+} \mathrm{C}_{12} \mathrm{H}_{12} \mathrm{NS}$ requires 202.0692, found: 202.0685 .

(m) With isopropyl magnesium chloride. Prepared following the procedure for $\mathbf{3 4}$ above, but using isopropyl magnesium chloride $(0.47 \mathrm{ml}, 2 \mathrm{M}$ in THF, $0.94 \mathrm{mmol})$. The product was purified by column chromatography cyclohexaneethyl acetate $(2: 1)$ to give 3-(2'-methylpropanethioyl) 4-methyl1,3-oxazolidin-2-one $\mathbf{4 2}$ as a yellow oil. Anal. calcd for $\mathrm{C}_{8} \mathrm{H}_{13} \mathrm{NO}_{2} \mathrm{~S}$ : C, 51.31; H, 7.00; N, 7.48\%; found: C, 51.26; H, 7.11; $\mathrm{N}, 7.58 \% . \delta_{\mathrm{H}}\left(400 \mathrm{MHz}, \mathrm{CDCl}_{3}\right): 5.10-5.17(1 \mathrm{H}, \mathrm{m}, 4-H), 4.29-$ $4.40\left(2 \mathrm{H}, \mathrm{m}, 2^{\prime}-, 5-H_{\alpha}\right), 3.99\left(1 \mathrm{H}, \mathrm{dd}, J=1.8,8.6 \mathrm{~Hz}, 5-H_{\beta}\right), 1.42$ $\left(3 \mathrm{H}, \mathrm{d}, J=6.3 \mathrm{~Hz}, 4-\mathrm{CH}_{3}\right), 1.16\left(6 \mathrm{H}, \mathrm{d}, J=6.4 \mathrm{~Hz}, 2 \times-\mathrm{CH}_{3}\right) ; \delta_{\mathrm{C}}$ $\left(100 \mathrm{MHz}, \mathrm{CDCl}_{3}\right): 219.5(C=\mathrm{S}), 150.4(2-C), 68.4$ (5-C), 55.8 (4$C), 38.4\left(2^{\prime}-C\right), 24.0\left(-C_{3}\right), 23.4\left(-C_{3}\right), 17.6\left(4-C_{3}\right), v_{\max }: 2973$, 1777, 1371, 1312, 1242, 1161, 1120, 1046, 914, 761, $698 \mathrm{~cm}^{-1}$; $m / z:(\mathrm{EI}) 187\left([\mathrm{M}]^{+}\right), 102,85,70,68,44 ; H R M S:(\mathrm{EI})$ for $[\mathrm{M}]^{+}$ $\mathrm{C}_{8} \mathrm{H}_{13} \mathrm{NO}_{2} \mathrm{~S}$ requires 187.0662 , found: 187.0663 .

\section{Rearrangement of 13 with tetrabutylammonium iodide to give} 32 and 33

(a) $\mathrm{Bu}_{4} \mathrm{NI}(550 \mathrm{mg}, 1.7 \mathrm{mmol})$ was added to a solution of rac 4-methyl-1,3-oxazolidine-2-thione 13 (200 mg, $1.7 \mathrm{mmol}$ ) dissolved in dry xylene $(10 \mathrm{ml})$. The mixture reaction was stirred for $30 \mathrm{~min}$. The glass tube was placed in an alumina bath inside the microwave oven (CEM Discover SP), and irradiated so that the internal temperature reached $145{ }^{\circ} \mathrm{C}$ for $1 \mathrm{~h}$. After cooling to room temperature, the reaction mixture was dissolved in dichloromethane and filtered, the solvent was evaporated and the crude compound purified by column chromatography using cyclohexane-ethyl acetate $(3: 1)$ which afforded the pure rac 4 - 
methyl-1,3-thiazolidin-2-one 32 (190 $\mathrm{mg}, 95 \%)$ as a yellow oil. Anal. calcd for $\mathrm{C}_{4} \mathrm{H}_{7} \mathrm{NOS}$ : C, 41.00; $\mathrm{H}, 6.02 ; \mathrm{N}, 11.95 \%$; found: $\mathrm{C}$, 41.02; H, 6.03; N, 11.89\%; $\delta_{\mathrm{H}}\left(400 \mathrm{MHz}, \mathrm{CDCl}_{3}\right): 7.07$ (1H, br-s, $\mathrm{N} H), 3.95(1 \mathrm{H}$, hex., $J=6.7 \mathrm{~Hz}, 4-H), 3.42(1 \mathrm{H}, \mathrm{dd}, J=7.1,10.8$ $\left.\mathrm{Hz}, 5-H_{\alpha}\right), 2.96\left(1 \mathrm{H}, \mathrm{dd}, J=7.2,10.8 \mathrm{~Hz}, 5-H_{\beta}\right), 1.28(3 \mathrm{H}, \mathrm{d}, J=$ $\left.6.3 \mathrm{~Hz}, \mathrm{CH}_{3}\right) ; \delta_{\mathrm{C}}\left(100 \mathrm{MHz}, \mathrm{CDCl}_{3}\right): 175.4(2-\mathrm{C}), 51.2(4-\mathrm{C}), 36.4$ (5-C), $20.3\left(\mathrm{CH}_{3}\right) ; v_{\max }: 3230,2971,1654,1355,1217$ and 684 $\mathrm{cm}^{-1}$; m/z: (GC-EIP) $117\left(\mathrm{M}^{+}\right), 102$; HRMS: (GC-EIP) for [M] $]^{+}$ $\mathrm{C}_{4} \mathrm{H}_{7} \mathrm{NOS}$ requires 117.0243 , found: 117.0241 .

(b) Using the procedure above but using a much smaller amount of dry xylene $(2 \mathrm{ml})$ and 1.5 eq. $\mathrm{Bu}_{4} \mathrm{NI}$ to obtain a rac - R, $R$ and $R, S$ - 4,9-dimethyl-1,6,3,8-dithiadiazocyclodecane-2,7dione 33 as a pale brown oil (110 mg, 27.7\%). Anal. calcd for $\mathrm{C}_{8} \mathrm{H}_{14} \mathrm{~N}_{2} \mathrm{O}_{2} \mathrm{~S}_{2}$ : C, 41.00; H, 6.02; N, 11.95\%; found: C, 41.14; H, $6.03 ; \mathrm{N}, 11.89 \% ; \delta_{\mathrm{H}}\left(400 \mathrm{MHz} \mathrm{CDCl}_{3}\right): 6.72(2 \mathrm{H}$, br-s, $2 \times \mathrm{NH})$, 3.87 (2H, hex., $J=6.7 \mathrm{~Hz}, 4-, 9-H), 3.64(2 \mathrm{H}, \mathrm{dd}, J=10.1,7.0 \mathrm{~Hz}$, 5-,10- $\left.H_{\alpha}\right), 3.17\left(2 \mathrm{H}, \mathrm{dd}, J=10.1,6.4 \mathrm{~Hz}, 5-, 10-H_{\beta}\right), 1.28(2 \times 3 \mathrm{H}$, $\left.\mathrm{d}, J=6.7 \mathrm{~Hz}, 2 \times \mathrm{CH}_{3}\right) ; \delta_{\mathrm{C}}\left(100 \mathrm{MHz}, \mathrm{CDCl}_{3}\right): 176.2(2 \times C=\mathrm{O})$, $50.6(4-, 9-C), 41.6(5-, 10-C), 20.8\left(2 \times C_{3}\right) ; v_{\text {max }}: 3231,2966$, 1869, 1661, 1215, 1060, 681 and $615 \mathrm{~cm}^{-1}$; m/z: (ESI) $235([\mathrm{M}+$ $\left.\mathrm{H}]^{+}\right), 201,158,140 . H R M S$ : for $[\mathrm{M}+\mathrm{H}]^{+} \mathrm{C}_{8} \mathrm{H}_{15} \mathrm{~N}_{2} \mathrm{O}_{2} \mathrm{~S}_{2}$ requires 235.0569, found: 235.0571 .

\section{Reactions of 16}

(a) With pyridine-2-thiolate. A solution of the sodium salt of 2-mercaptopyridine in dry THF (15 ml), formed from 2-mercaptopyridine (122 mg, $1.1 \mathrm{mmol})$ and sodium hydride $(60 \%$ dispersion in mineral oil, $71 \mathrm{mg}, 1.78 \mathrm{mmol}$ ), was added to a solution of thionocarbamate $16(261 \mathrm{mg}, 1.0 \mathrm{mmol})$. After stirring at room temperature overnight, drops of $20 \%$ acetic acid were added, and the mixture left to stir for $30 \mathrm{~min}$. The solvent was evaporated, and the residue was extracted with dichloromethane $(2 \times 20 \mathrm{ml})$ and the extract washed with water $(30 \mathrm{ml})$. The crude product was purified by chromatography using cyclohexane-ethyl acetate $(1: 2)$ to furnish rac methyl 2-((tertbutoxycarbonyl)amino)-3-(pyridin-2-ylthio)propanoate 29 (177 $\mathrm{mg}, 56.7 \%$ ) as a yellow oil. Anal. calcd for $\mathrm{C}_{14} \mathrm{H}_{20} \mathrm{~N}_{2} \mathrm{O}_{4} \mathrm{~S}: \mathrm{C}$, $53.62 ; \mathrm{H}, 6.45 ; \mathrm{N}, 8.97 \%$, found: $\mathrm{C}, 53.62 ; \mathrm{H}, 6.47 ; \mathrm{N}, 8.88 \% . \delta_{\mathrm{H}}$ $\left(400 \mathrm{MHz}, \mathrm{CDCl}_{3}\right): 8.32\left(1 \mathrm{H}, \mathrm{br}-\mathrm{d}, J=4.0 \mathrm{~Hz}, 6^{\prime}-H\right), 7.41(1 \mathrm{H}, \mathrm{dt}$, $\left.J=1.8,7.3 \mathrm{~Hz}, 4^{\prime}-H\right), 7.14\left(1 \mathrm{H}, \mathrm{d}, J=8.0 \mathrm{~Hz}, 3^{\prime}-H\right), 6.93-6.97(1 \mathrm{H}$, $\left.\mathrm{m}, 5^{\prime}-H\right), 6.26(1 \mathrm{H}, \mathrm{s}, \mathrm{NH}), 4.50(1 \mathrm{H}, \mathrm{m}, 2-H), 3.63\left(3 \mathrm{H}, \mathrm{s}, \mathrm{OCH}_{3}\right)$, 3.48-3.58 (2H, m, 3- $\left.\mathrm{H}_{2}\right), 1.33\left(9 \mathrm{H}, \mathrm{s}, 3 \times \mathrm{CH}_{3}\right) ; \delta_{\mathrm{C}}(400 \mathrm{MHz}$, $\left.\mathrm{CDCl}_{3}\right): 171.4(1-C), 157.6\left(2^{\prime}-\mathrm{C}\right), 155.5(\mathrm{~N}-C=\mathrm{O}), 149.7\left(6^{\prime}-C\right)$, $136.2\left(4^{\prime}-C\right), 122.5\left(3^{\prime}-C\right), 119.9\left(5^{\prime}-C\right), 79.9\left(C-\left(\mathrm{CH}_{3}\right)_{3}\right), 54.4(2-C)$, $52.2\left(\mathrm{OCH}_{3}\right), 31.9(3-\mathrm{C}), 28.2\left(3 \times \mathrm{CH}_{3}\right), v_{\max }: 3352,2961,1744$, 1711, 1578, 1454, 1416, 1365, 1258, 1164, 1017, 797, 761 and 401 $\mathrm{cm}^{-1} ; \mathrm{m} / z$ : (EI) $312\left([\mathrm{M}]^{+}\right), 239,219,196 ; H R M S$ : (EI) for $[\mathrm{M}]^{+}$ $\mathrm{C}_{14} \mathrm{H}_{20} \mathrm{~N}_{2} \mathrm{O}_{4} \mathrm{~S}$ requires 312.1138 , found: 312.1136 .

(b) With phenylthiolate. Sodium hydride (60\% dispersion in mineral oil, $71 \mathrm{mg}, 1.78 \mathrm{mmol}$ ) was added to anhydrous methanol $(10 \mathrm{ml})$ and the mixture stirred at room temperature for $30 \mathrm{~min}$. Dry thiophenol $(0.28 \mathrm{ml}, 2.67 \mathrm{mmol})$ was added and the mixture was stirred for a further $30 \mathrm{~min}$ after which time thionocarbamate 16 (261 mg, $1.0 \mathrm{mmol}$ ) was added. After stirring at room temperature overnight, a few drops of $20 \%$ acetic acid were added and the reaction mixture was evaporated. The residue was extracted with diethyl ether, dried and concentrated in vacuo. Final purification was achieved by column chromatography with ethyl acetate as eluent to give rac methyl 2-((tertbutoxycarbonyl)amino)-3-(phenylthio)propanoate 30 (216 mg, $69.5 \%$ ) as clear oil. Anal. calcd for $\mathrm{C}_{15} \mathrm{H}_{21} \mathrm{NO}_{4} \mathrm{~S}: \mathrm{C}, 57.86 ; \mathrm{H}$, $6.80 ; \mathrm{N}, 4.50 \%$; found: C, 57.85; H, 6.81; N, 4.41\%; $\delta_{\mathrm{H}}(400 \mathrm{MHz}$, $\left.\mathrm{CDCl}_{3}\right)$ : 7.39-7.15 (5H, m, Ar- $\left.H_{5}\right), 5.32(1 \mathrm{H}, \mathrm{s}, \mathrm{NH}), 4.50-4.58$ $(1 \mathrm{H}, \mathrm{m}, 2-\mathrm{H}), 3.45\left(3 \mathrm{H}, \mathrm{s}, \mathrm{OCH}_{3}\right), 3.28-3.32\left(2 \mathrm{H}, \mathrm{m}, 3-\mathrm{H}_{2}\right), 1.43$ $\left(9 \mathrm{H}, \mathrm{s}, 3 \times \mathrm{CH}_{3}\right) ; \delta_{\mathrm{C}}\left(100 \mathrm{MHz}, \mathrm{CDCl}_{3}\right): 170.8(1-\mathrm{C}), 154.8(\mathrm{~N}-\mathrm{C}=$ O), 134.8 (ipso-C), $130.5(2 \times$ meta- $C), 129.0(2 \times$ ortho- $C), 126.8$ (para-C), $79.9\left(\mathrm{C}-\left(\mathrm{CH}_{3}\right)_{3}\right), 53.7(2-\mathrm{C}), 52.1\left(\mathrm{OCH}_{3}\right), 37.0(3-\mathrm{C}), 28.2$ $\left(3 \times \mathrm{CH}_{3}\right)$; $v_{\text {max }}: 3373,2977,1746,1712,1499,1438,1366,1161$, 1053, 1011, 742 and $691 \mathrm{~cm}^{-1} ; \mathrm{m} / z$ : (EI) $311\left([\mathrm{M}]^{+}\right), 193,122$, 56; HRMS: (EI) for $[\mathrm{M}]^{+} \mathrm{C}_{15} \mathrm{H}_{21} \mathrm{NO}_{4} \mathrm{~S}$ requires 311.1186, found: 311.1183 . Compound $\mathbf{3 0}$ has been briefly referred to before. $^{34}$

(c) With phenyl lithium. Phenyl lithium ( $84 \mathrm{mg}, 0.56 \mathrm{ml}, 1.1$ $\mathrm{mmol}$ ) was added to a stirred solution of thionocarbamate 16 (261 $\mathrm{mg}, 1.0 \mathrm{mmol})$ in anhydrous tetrahydrofuran $(15 \mathrm{ml})$ under a nitrogen atmosphere at $-78{ }^{\circ} \mathrm{C}$, and the solution was stirred under anhydrous conditions. The solution was allowed to warm to $20{ }^{\circ} \mathrm{C}$ and was stirred overnight and became yellow. After adding some drops of a mixture of aqueous THF and stirring for $30 \mathrm{~min}$, the solvent was evaporated, the residue was extracted with dichloromethane $(2 \times 20 \mathrm{ml})$ and the extract was washed with water $(30 \mathrm{ml})$. The organic layer was evaporated and the resulting residue was chromatographed on silica using ethyl acetate-cyclohexane $(1: 2)$ to give two known products: 2 -tertbutoxycarbonylamino-acrylic acid methyl ester $\mathbf{4 4}^{\mathbf{3 4 , 3 5}}$ as a yellow oil $(105 \mathrm{mg}, 52.3 \%), \delta_{\mathrm{H}}\left(400 \mathrm{MHz}, \mathrm{CDCl}_{3}\right): 6.96(1 \mathrm{H}, \mathrm{s}, \mathrm{NH}), 6.10(1 \mathrm{H}$, br-s, 3- $\left.H_{\alpha}\right), 5.65\left(1 \mathrm{H}, \mathrm{d}, J=1.5 \mathrm{~Hz}, 3-H_{\beta}\right), 3.74\left(3 \mathrm{H}, \mathrm{s}, \mathrm{OCH}_{3}\right), 1.31$ $\left(9 \mathrm{H}, \mathrm{s}, 3 \times \mathrm{CH}_{3}\right), \delta_{\mathrm{C}}\left(100 \mathrm{MHz}, \mathrm{CDCl}_{3}\right): 164.4(1-\mathrm{C}), 152.4(\mathrm{~N}-\mathrm{C}=$ O), $131.2(2-\mathrm{C}), 105.1(3-\mathrm{C}), 80.6\left(C-\left(\mathrm{CH}_{3}\right)_{3}\right), 52.7\left(\mathrm{OCH}_{3}\right), 28.2(3 \times$ $\left.\mathrm{CH}_{3}\right)$; $v_{\max }: 3356,2973,1741,1700,1510,1366,1222,1151,1055$, 1018, 751, 699, 498 and $382 \mathrm{~cm}^{-1}$ and methyl 2-((tert-butoxycarbonyl)amino)-3-phenylpropanoate $\mathbf{4 5}^{\mathbf{3 6}}$ as a pale yellow solid (81 mg, 29.1\%), m.p. 89-91 ${ }^{\circ} \mathrm{C}$. Anal. calcd for $\mathrm{C}_{15} \mathrm{H}_{21} \mathrm{NO}_{4}: \mathrm{C}$, $64.50 ; \mathrm{H}, 7.58 ; \mathrm{N}, 5.00 \%$; found: $\mathrm{C}, 64.42 ; \mathrm{H}, 7.63 ; \mathrm{N}, 4.95 \% ; \delta_{\mathrm{H}}$ $\left(400 \mathrm{MHz}, \mathrm{CDCl}_{3}\right): 7.05-7.28\left(5 \mathrm{H}, \mathrm{m}, \mathrm{Ar}-H_{5}\right), 4.91(1 \mathrm{H}, \mathrm{s}, \mathrm{NH})$, 4.49-4.53 (1H, m, 2-H), $3.63\left(3 \mathrm{H}, \mathrm{s}, \mathrm{OCH}_{3}\right), 2.92-3.06(2 \mathrm{H}, \mathrm{m}, 3-$ $\left.H_{2}\right), 1.39\left(9 \mathrm{H}, \mathrm{s}, 3 \times \mathrm{CH}_{3}\right) ; \delta_{\mathrm{C}}\left(100 \mathrm{MHz}, \mathrm{CDCl}_{3}\right): 172.0(1-\mathrm{C}), 155.1$ $(\mathrm{N}-C=\mathrm{O}), 135.9($ ipso- $C), 129.2(2 \times$ meta- $C), 128.5(2 \times$ ortho- $C)$, 126.9 (para- $C), 79.9\left(C-\left(\mathrm{CH}_{3}\right)_{3}\right), 54.3(2-C), 52.2\left(\mathrm{OCH}_{3}\right), 38.3(3-C)$, $28.2\left(3 \times \mathrm{CH}_{3}\right) ; v_{\text {max }}: 3356,2973,1741,1700,1510,1366,1222$, 1151, 1055, 1018, 751, 699, 498 and $382 \mathrm{~cm}^{-1} ; \mathrm{m} / \mathrm{z}$ : (ESI) $302([\mathrm{M}+$ $\left.\mathrm{Na}]^{+}\right), 180,149$.

\section{X-ray crystallography}

Data was collected with MoK $\alpha$ radiation at $120-150 \mathrm{~K}$ on a Bruker Nonius diffractometer equipped with a rotating anode source, and a $95 \mathrm{~mm}$ CCD camera by the EPSRC National X-ray Crystallography Service at Southampton University for $\mathbf{1 1}$ and 14 or on an Agilent Xcalibur diffractometer equipped with a Sapphire detector at Nottingham Trent University for 17, 31 and 35-37. Structures were solved and refined with the SHELXS and SHELXL suite of programs ${ }^{37}$ using the XSEED ${ }^{38}$ interface, and 
molecular illustrations are prepared with Mecury ${ }^{39}$ and POV$\mathrm{RAY}^{40}$

Crystal data for 11: $\mathrm{C}_{11} \mathrm{H}_{13} \mathrm{NSO}, M_{\mathrm{r}}=207.3$, orthorhombic, $a=19.5407(9), b=8.0050(4), c=6.7851(3) \AA, V=1061.35(9) \AA^{3}$, $P 2{ }_{1} 2{ }_{1} 2, Z=4, D_{\text {calc. }}=1.297 \mathrm{~g} \mathrm{~cm}^{-3}, T=120 \mathrm{~K}, \mu=0.271 \mathrm{~mm}^{-1}$, $F(000)=440,2439$ unique reflections, 2242 with $I>2 \sigma(I)$, max. $(\sin \theta) / \lambda=0.65 \AA^{-1}$, final $R=0.027, \mathrm{w} R=0.069$. Crystals grown from dichloromethane.

Crystal data for 14: $\mathrm{C}_{9} \mathrm{H}_{15} \mathrm{NSO}_{3}, M_{\mathrm{r}}=217.2$, monoclinic, $a=$ 7.4816(2), $b=15.2728(4), c=9.6621(3) \AA, \beta=97.115(2)^{\circ}, V=$ 1095.54(5) $\AA^{3}, P 2_{1} / a, Z=4, D_{\text {calc. }}=1.317 \mathrm{~g} \mathrm{~cm}^{-3}, T=120 \mathrm{~K}, \mu=$ $0.278 \mathrm{~mm}^{-1}, F(000)=464,2506$ unique reflections, 2183 with $I>2 \sigma(I)$, max. $(\sin \theta) / \lambda=0.65 \AA^{-1}$, final $R=0.029, \mathrm{w} R=0.070$. Crystals grown from ethyl acetate.

Crystal data for 17: $\mathrm{C}_{9} \mathrm{H}_{15} \mathrm{NO}_{4}, M_{\mathrm{r}}=201.2$, orthorhombic, $a=$ 9.1981(4), $b=9.2778(3), c=23.4543(11) \AA, V=2001.55(14) \AA^{3}$, Pbca, $Z=8, D_{\text {calc. }}=1.34 \mathrm{~g} \mathrm{~cm}^{-3}, T=120 \mathrm{~K}, \mu=0.105 \mathrm{~mm}^{-1}$, $F(000)=864,2376$ unique reflections, 1819 with $I>2 \sigma(I)$, final $R=0.049, \mathrm{w} R=0.095$. Crystals grown from ether.

Crystal data for 31: $\mathrm{C}_{9} \mathrm{H}_{15} \mathrm{NO}_{3} \mathrm{~S}, M_{\mathrm{r}}=217.3$, monoclinic, $a=$ 9.6972 (6), $b=6.7661$ (3), $c=17.4884(10) \AA, ~ \beta=100.177(3)^{\circ}$, $V=1129.40(11) \AA^{3}, P 2_{1} / n, Z=4, D_{\text {calc. }}=1.28 \mathrm{~g} \mathrm{~cm}^{-3}, T=120 \mathrm{~K}$, $\mu=0.270 \mathrm{~mm}^{-1}, F(000)=464,2390$ unique reflections, 1996 with $I>2 \sigma(I)$, final $R=0.052, \mathrm{w} R=0.119$. Crystals grown from ethyl acetate.

Crystal data for 36: $\mathrm{C}_{13} \mathrm{H}_{25} \mathrm{NO}_{3} \mathrm{~S}, M_{\mathrm{r}}=275.4$, monoclinic, $a=$ 11.4804(3), $b=9.9540(3), c=28.7919(8) \AA, \beta=90.00(3)^{\circ}, V=$ $3290.22(16) \AA^{3}, P 2_{1} / c, Z=8, D_{\text {calc. }}=1.11 \mathrm{~g} \mathrm{~cm}^{-3}, T=150 \mathrm{~K}$, $\mu=0.198 \mathrm{~mm}^{-1}, F(000)=1200,7791$ unique reflections, 5508 with $I>2 \sigma(I)$, final $R=0.064, \mathrm{w} R=0.15$. Twinned crystal, twin

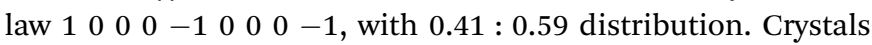
grown from ethyl acetate.

Crystal data for 37: $\mathrm{C}_{11} \mathrm{H}_{2} \mathrm{~N}_{2} \mathrm{O}_{3} \mathrm{~S}, M_{\mathrm{r}}=262.37$, monoclinic, $a=13.1321(4), b=11.0452(3), c=10.1525(3) \AA, \beta=100.532(3)^{\circ}$, $V=1447.78(7) \AA^{3}, P 21 / c, Z=4, D_{\text {calc. }}=1.20 \mathrm{~g} \mathrm{~cm}^{-3}, T=150 \mathrm{~K}$, $\mu=0.223 \mathrm{~mm}^{-1}, F(000)=568,3569$ unique reflections, 2818 with $I>2 \sigma(I)$, final $R=0.039, \mathrm{w} R=0.11$. Crystals grown from ethyl acetate.

Crystal data for 38: $\mathrm{C}_{16} \mathrm{H}_{30} \mathrm{~N}_{2} \mathrm{O}_{5} \mathrm{~S}, M_{\mathrm{r}}=362.48$, monoclinic, $a=5.9611(2), b=19.2487(6), c=17.6222(5) \AA$, $\beta=94.909(3)^{\circ}$, $V=2014.61(11) \AA^{3}, P 2_{1} / n, Z=4, D_{\text {calc. }}=1.19 \mathrm{~g} \mathrm{~cm}^{-3}, T=150 \mathrm{~K}$, $\mu=0.186 \mathrm{~mm}^{-1}, F(000)=784,4614$ unique reflections, 3514 with $I>2 \sigma(I)$, final $R=0.040, \mathrm{w} R=0.010$. Crystals grown from ethyl acetate.

\section{Acknowledgements}

We thank the Libyan Ministry of Higher Education and AlMergheb University for a PhD scholarship (IA). This work was also supported in part by the Scientific and Technological Research Council of Turkey (TUBITAK) by grant TBAG-2459 (104T070). We thank Dr. S. Ko for interesting discussions, EPSRC National Crystallography Service at Southampton University (Dr. S. J. Coles) for datasets, EPSRC National Mass Spectrometry Service Centre at Swansea University (Prof. A. G. Brenton) for measurements and the Chemical Database Service at Daresbury. ${ }^{\mathbf{4 1}}$

\section{References}

1 (a) H. C. Kolb, M. S. Van Nieuwenhze and K. B. Sharpless, Chem. Rev., 1994, 94, 2483-2547; (b) H. C. Kolb and K. B. Sharpless, in Transition Metals for Organic Synthesis, ed. M. Beller and C. Bolm, Wiley-VCH, Weinheim, Germany, 2004, 2nd edn, vol. 2, pp. 275-298.

2 (a) G. G. Li, H. T. Chang and K. B. Sharpless, Angew. Chem., Int. Ed. Engl., 1996, 35, 451-454; (b) H. C. Kolb and K. B. Sharpless, in Transition Metals for Organic Synthesis, ed. M. Beller and C. Bolm, Wiley-VCH, Weinheim, 2004, 2nd edn, vol. 2, pp. 309-326.

3 (a) Y. Gao and K. B. Sharpless, J. Am. Chem. Soc., 1988, 110, 7538-7539; (b) B. B. Lohray, Synthesis, 1992, 1035-1052.

4 M. Pound, D. L. Davies, M. Pilkington, M. Pina vaz Sousa and J. D. Wallis, Tetrahedron Lett., 2002, 43, 1915-1918.

5 J. D. Wallis, A. Karrer and J. D. Dunitz, Helv. Chim. Acta, 1986, 69, 69-70.

6 R. Oi and K. B. Sharpless, Tetrahedron Lett., 1991, 32, 9991002.

7 B. B. Lohray, Y. Gao and K. B. Sharpless, Tetrahedron Lett., 1989, 30, 2623-2626.

8 M. Pilkington and J. D. Wallis, J. Chem. Soc., Chem. Commun., 1993, 1857-1858.

9 J. E. Baldwin, A. C. Spivey and C. J. Schofield, Tetrahedron: Asymmetry, 1990, 1, 881-884.

10 N. Ashkenazi, S. S. Zade, Y. Segali, Y. Karton and M. Bendikov, Chem. Commun., 2005, 5879-5881.

11 (a) S. Y. Ko, J. Org. Chem., 1995, 60, 6250-6251; (b) G. Y. Cho and S. Y. Ko, J. Org. Chem., 1999, 64, 8745-8747.

12 (a) M. Alpegiani and S. Hanessian, J. Org. Chem., 1987, 52, 278279; (b) H.-S. Rho, Synth. Commun., 1998, 28, 843-847; (c) D. O. Jang and S. H. Song, Tetrahedron Lett., 2000, 41, 247-249.

13 L. Faissat, C. Chavis, J.-L. Montero and M. Lucas, J. Chem. Soc., Perkin Trans. 1, 2002, 1253-1259.

14 (a) M. T. Crimmins, B. W. King and E. A. Tabet, J. Am. Chem. Soc., 1997, 119, 7883-7884; (b) E. Fujita and Y. Nagao, Adv. Heterocycl. Chem., 1989, 45, 1-36; (c) M. El Sous, D. Ganame, P. A. Tregloan and M. A. Rizzacasa, Org. Lett., 2004, 6, 3001-3004.

15 M. C. Willis, G. A. Cutting, V. J.-D. Piccio, M. J. Durbin and M. P. John, Angew. Chem., Int. Ed., 2005, 44, 1543-1545.

16 K. Blazewska and T. Gajda, Tetrahedron, 2004, 60, 11701-11707. 17 G. T. Notte, T. Sammakia and P. J. Steel, J. Am. Chem. Soc., 2005, 127, 13502-13503.

18 J. M. García Fernández, C. Ortiz Mellet and J. Fuentes, J. Org. Chem., 1993, 58, 5192-5199.

19 D. E. Ward and B. F. Kaller, J. Org. Chem., 1994, 59, 42304238.

20 B. K. Goering and B. Ganem, Tetrahedron Lett., 1994, 35, 6997-7000.

21 Y. Wu, Y.-Q. Yang and Q. Hu, J. Org. Chem., 2004, 69, 39903992.

22 M. T. Crimmins, B. W. King, E. A. Tabet and K. Chaudhary, J. Org. Chem., 2001, 66, 894-902.

23 Cambridge Structural Database, F. H. Allen, Acta Crystallogr., Sect. B: Struct. Sci., 2002, 58, 380-388. 
24 Structures with $R$ value $\leq 0.06$, average $\sigma(\mathrm{C}-\mathrm{C}): 0.001-0.005$ A, $T$ : 93-123 K, refcodes: CUHRED, CURWES, JIPWUB, OZIFOT, ROHFAW, UJOHAC, UJOHEG, ZAXMIW.

25 Structures with $R$ value $\leq 0.06$, average $\sigma(\mathrm{C}-\mathrm{C}): 0.001-$ $0.005 \AA$ A $T:$ 100-173 K, refcodes: EHAJIG, RAYNIP, XICPOO.

26 P. Gritsonie, M. Pilkington, J. D. Wallis and D. C. Povey, Acta Crystallogr., Sect. C: Cryst. Struct. Commun., 1994, 50, 763765.

27 J. Han, S. Kang and H.-K. Lee, Chem. Commun., 2011, 47, 4004-4006.

28 N. Saygili, Daru, J. Pharm. Sci., 2011, 31, 15-26.

29 (a) A. López-Castro, E. Moreno and S. Perez-Garrido, Carbohydr. Res., 1991, 209, 285-288; (b) M. Marc, F. Outurquin, P.-Y. Renard, C. Créminon and X. Franck, Tetrahedron Lett., 2009, 50, 4554-4557; (c) R. Sabala, L. Hernández-García, A. Ortiz, M. Romero and H. F. Olivo, Org. Lett., 2010, 12, 4268-4270; (d) I. Caracelli, D. C. S. Coelho, P. R. Olivato, T. C. Correra, A. Rodrigues and E. R. T. Tiekink, Acta Crystallogr., Sect. E: Struct. Rep. Online, 2011, 67, o2755-o2766.

30 H. M. Wang, H. X. Li, S. Y. Yu, Z. G. Ren and J. P. Lang, Tetrahedron, 2011, 67, 1530-1535.

31 (a) E. H. M. Abd Elall, M. I. Al Ashmawy and J. M. Mellor, J. Chem. Soc., Perkin Trans. 1, 1987, 2729-2736; (b)
S. Mourtas, C. Katakalou, A. Nicolettou, C. Tzavara, D. Gatos and K. Barlos, Tetrahedron Lett., 2003, 44, 179-182. 32 Y. B. Yu, H. L. Chen, L. Y. Wang, X. Z. Chen and B. Fu, Molecules, 2009, 14, 4858-4865.

33 M. Viscontini, Helv. Chim. Acta, 1950, 33, 2251-2253.

34 G. A. Flynn and D. W. Beight, Tetrahedron Lett., 1984, 25, 2655-2658.

35 (a) N. Tamura, Y. Matsushita, K. Yoshioka and M. Ochiai, Tetrahedron, 1988, 44, 3231-3240; (b) J. M. Benito and M. Meldal, QSAR Comb. Sci., 2004, 23, 117-129.

36 L. Navarre, R. Martinez, J.-P. Genet and S. Darses, J. Am. Chem. Soc., 2008, 130, 6159-6169.

37 G. M. Sheldrick, Acta Crystallogr., Sect. A: Fund. Crystallogr., 2008, 64, 112-122.

38 L. J. Barbour, X-Seed - A software tool for supramolecular crystallography, J. Supramol. Chem., 2001, 1, 189-191.

39 C. F. Macrae, P. R. Edgington, P. McCabe, E. Pidcock, G. P. Shields, R. Taylor, M. Towler and J. van de Streek, J. Appl. Crystallogr., 2006, 39, 453-457.

40 Persistence of VisionPty. Ltd., Persistence of Vision (TM) Raytrace, Persistence of Vision Pty. Ltd., Williamstown, Victoria, Australia, 2004, http://www.povray.org.

41 The United Kingdom Chemical Database Service, D. A. Fletcher, R. F. McMeeking and D. J. Parkin, J. Chem. Inf. Comput. Sci., 1996, 36, 746-749. 